\title{
Reactions of (Arylimido)vanadium(V)-Trialkyl Complexes with Phenols: Effects of Arylimido Ligands and Phenols for Formation of the Vanadium Phenoxides
}

\author{
Hitomi Hayashibara, Aurapat Ngamnithiporn, ${ }^{\dagger}$ and Kotohiro Nomura*(i) \\ Department of Chemistry, Tokyo Metropolitan University, 1-1 Minami Osawa, Hachioji, Tokyo 192-0397, Japan
}

Supporting Information

\begin{abstract}
Reactions of a series of (arylimido)vanadium(V) trialkyl complexes, $\mathrm{V}\left(\mathrm{NAr}^{\prime}\right)\left(\mathrm{CH}_{2} \mathrm{SiMe}_{3}\right)_{3}\left(\mathrm{Ar}^{\prime}=\mathrm{C}_{6} \mathrm{H}_{5}, 2-\mathrm{MeC}_{6} \mathrm{H}_{4}, 2,6-\mathrm{Me}_{2} \mathrm{C}_{6} \mathrm{H}_{3}\right.$, 2,6- $\left.\mathrm{Cl}_{2} \mathrm{C}_{6} \mathrm{H}_{3}\right)$, with various phenols $\left(\mathrm{ArOH}, \mathrm{Ar}=2,6-\mathrm{F}_{2} \mathrm{C}_{6} \mathrm{H}_{3}, 2,6-\mathrm{Cl}_{2} \mathrm{C}_{6} \mathrm{H}_{3}\right.$, 2,6- $-\mathrm{Me}_{2} \mathrm{C}_{6} \mathrm{H}_{3}, 2,6-{ }^{i} \mathrm{Pr}_{2} \mathrm{C}_{6} \mathrm{H}_{3}, 2-{ }^{t} \mathrm{BuC}_{6} \mathrm{H}_{4}, 2,6-{ }^{t} \mathrm{Bu}_{2} \mathrm{C}_{6} \mathrm{H}_{3} ; 1.0$ equiv) affording $\mathrm{V}\left(\mathrm{NAr}^{\prime}\right)\left(\mathrm{CH}_{2} \mathrm{SiMe}_{3}\right)_{2}(\mathrm{OAr})$ were conducted in $\mathrm{C}_{6} \mathrm{D}_{6}$ at $25^{\circ} \mathrm{C}$, and the effects of both arylimido ligands and phenols on the substitution rate were explored. Sterically hindered arylimido ligands showed lower reactivity, and the reaction proceeded in the order: $\mathrm{Ar}^{\prime}=2,6-\mathrm{Me}_{2} \mathrm{C}_{6} \mathrm{H}_{3}<2,6-\mathrm{Cl}_{2} \mathrm{C}_{6} \mathrm{H}_{3}<2$ $\mathrm{MeC}_{6} \mathrm{H}_{4}<\mathrm{C}_{6} \mathrm{H}_{5}$. This order is somewhat different from that obtained from the chemical shifts in $\mathrm{V}\left(\mathrm{NAr}^{\prime}\right)\left(\mathrm{CH}_{2} \mathrm{SiMe}_{3}\right)_{3}$ in the ${ }^{51} \mathrm{~V}$ NMR spectra. The conversions with various disubstituted phenols increased in the order: $2,6-{ }^{i} \mathrm{Pr}_{2} \mathrm{C}_{6} \mathrm{H}_{3} \mathrm{OH}<2,6-\mathrm{Me}_{2} \mathrm{C}_{6} \mathrm{H}_{3} \mathrm{OH}<2,6-\mathrm{Cl}_{2} \mathrm{C}_{6} \mathrm{H}_{3} \mathrm{OH}<2,6-\mathrm{F}_{2} \mathrm{C}_{6} \mathrm{H}_{3} \mathrm{OH}$, irrespective of the kind of arylimido ligands. The reactions of $\mathrm{V}\left(\mathrm{NAr}^{\prime}\right)$ -

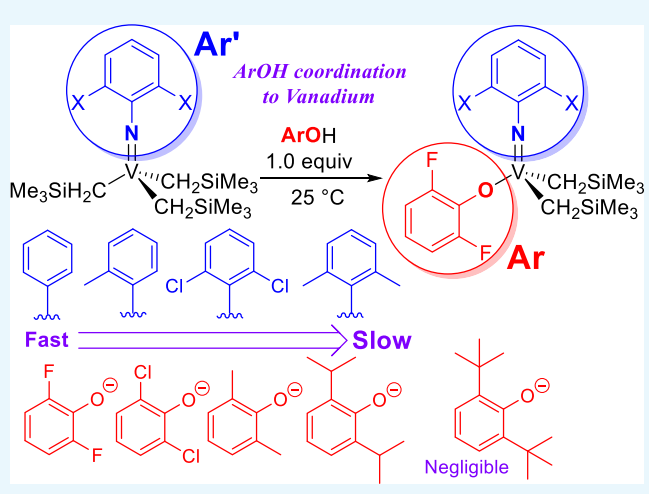
$\left(\mathrm{CH}_{2} \mathrm{SiMe}_{3}\right)_{3}$ with $2,6{ }^{\mathrm{t}} \mathrm{Bu}_{2} \mathrm{C}_{6} \mathrm{H}_{3} \mathrm{OH}$ (1.0 or 3.0 equiv) did not take place even upon heating at $60{ }^{\circ} \mathrm{C}$. These results suggest that the reactions proceed via coordination of $\mathrm{ArOH}$ toward vanadium, and the reactivity is highly dependent on steric bulk of both the arylimido ligand and the phenol.
\end{abstract}

\section{INTRODUCTION}

Transition-metal alkyl complexes are among the most important reagents or intermediates in organic reactions, ${ }^{1-4}$ and the study of their reaction chemistry has been recognized as an important subject for better understanding especially in catalysis cycles, reaction pathways, and design of efficient catalysts. ${ }^{1-4}$ The metal alkyl species play a key role in olefin polymerization, the core technology for the production of polyolefins in the chemical industry. ${ }^{-18}$ Since classical Ziegler type vanadium catalyst systems display unique characteristics (highly reactive toward olefins exemplified as production of ultrahigh molecular weight polyethylene with narrow molecular weight distributions), ${ }^{19-21}$ the reaction chemistry of vanadium-alkyl complexes ${ }^{22-38}$ should be considered as an important subject in the field of catalysis $^{12,38-41}$ and organometallic chemistry. ${ }^{42-44}$

Early transition-metal-alkyl bonds have been known to be more nucleophilic than those with late transition metals, and these are thus highly reactive toward Brönsted/Lewis acids. ${ }^{1-5}$ For example, cationic alkyl complexes, proposed active species for olefin polymerization, are formed by treating the dialkyl analogues with $\mathrm{Al}$ alkyls or borate through protonolysis or alkyl abstraction. $^{5-18,40,41}$ These metal alkyls are generally rapidly reacted with alcohols (or phenols, ArOH) via protonation or coordination and a subsequent hydrogen transfer pathway (Scheme 1). It has been, however, reported that steric crowding in tetrakis(alkyl)-chromium(IV) $)^{45,46}$ and zirconium(IV) ${ }^{49}$ complexes [exemplified as $\mathrm{Cr}^{t} \mathrm{Bu}_{4}$ and $\mathrm{Zr}\left(\mathrm{CH}_{2}{ }^{t} \mathrm{Bu}\right)_{4}$ ] and (arylimido)vanadium $(\mathrm{V})$ trialkyl complex (described below) ${ }^{48}$ contributes to greater stability toward oxygen and alcohols. For example, Wolczanski et al. ${ }^{47}$ reported that the synthesis of $\mathrm{Zr}\left(\mathrm{CH}_{2}{ }^{t} \mathrm{Bu}\right)_{3}\left(\mathrm{OC}^{t} \mathrm{Bu}_{3}\right)$ from $\mathrm{Zr}\left(\mathrm{CH}_{2}{ }^{t} \mathrm{Bu}\right)_{4}$ by treating with ${ }^{t} \mathrm{Bu}_{3} \mathrm{COH}$ (1.61 equiv) in benzene required $30 \mathrm{~h}$ under reflux conditions $\left(93-95{ }^{\circ} \mathrm{C}\right)$, whereas the synthesis of $\mathrm{Zr}$ $\left(\mathrm{CH}_{2} \mathrm{Ph}\right)_{3}\left(\mathrm{OC}^{t} \mathrm{Bu}_{3}\right)$ from $\mathrm{Zr}\left(\mathrm{CH}_{2} \mathrm{Ph}\right)_{4}$ with ${ }^{t} \mathrm{Bu}_{3} \mathrm{COH}$ (1.14 equiv) required only $7 \mathrm{~h}^{47}$

Moreover, the reaction of $\mathrm{V}\left(\mathrm{N}-2,6-\mathrm{Me}_{2} \mathrm{C}_{6} \mathrm{H}_{3}\right)\left(\mathrm{CH}_{2} \mathrm{SiMe}_{3}\right)_{3}$ with excess $2,6-{ }^{t} \mathrm{Bu}_{2}-4-\mathrm{MeC}_{6} \mathrm{H}_{2} \mathrm{OH}$ (2.6 equiv) in $\mathrm{C}_{2} \mathrm{D}_{2} \mathrm{Cl}_{4}$ at 50 ${ }^{\circ} \mathrm{C}$ did not take place, whereas most reactions of $\mathrm{V}(\mathrm{N}-2,6$ $\left.\mathrm{Me}_{2} \mathrm{C}_{6} \mathrm{H}_{3}\right)\left(\mathrm{CH}_{2} \mathrm{SiMe}_{3}\right)_{3}$ with 1.0 equiv of less sterically hindered phenols and alcohols afforded the corresponding dialkyl complexes exclusively at $25{ }^{\circ} \mathrm{C}$ (Scheme 2). ${ }^{48}$ Synthesis of $\mathrm{V}\left(\mathrm{N}-2,6-\mathrm{Me}_{2} \mathrm{C}_{6} \mathrm{H}_{3}\right)\left(\mathrm{CH}_{2} \mathrm{SiMe}_{3}\right)\left(\mathrm{O}-2,6-\mathrm{Me}_{2} \mathrm{C}_{6} \mathrm{H}_{3}\right)_{2}$ from $\mathrm{V}\left(\mathrm{N}-2,6-\mathrm{Me}_{2} \mathrm{C}_{6} \mathrm{H}_{3}\right)\left(\mathrm{CH}_{2} \mathrm{SiMe}_{3}\right)_{2}\left(\mathrm{O}-2,6-\mathrm{Me}_{2} \mathrm{C}_{6} \mathrm{H}_{3}\right)$ by treating with 2,6- $\mathrm{Me}_{2} \mathrm{C}_{6} \mathrm{H}_{3} \mathrm{OH}$ required $50 \mathrm{~h}$ at $60{ }^{\circ} \mathrm{C}$ for completion, and the reaction did not take place (or was too slow) at $25^{\circ} \mathrm{C}$. In contrast, immediate phenoxide ligand exchange was observed when $\mathrm{V}\left(\mathrm{N}-2,6-\mathrm{Me}_{2} \mathrm{C}_{6} \mathrm{H}_{3}\right)\left(\mathrm{CH}_{2} \mathrm{SiMe}_{3}\right)_{2}\left(\mathrm{O}-2,6-\mathrm{Me}_{2} \mathrm{C}_{6} \mathrm{H}_{3}\right)$ was treated with 1.0 equiv of $\mathrm{C}_{6} \mathrm{~F}_{5} \mathrm{OH}$ at $25^{\circ} \mathrm{C}$ (Scheme 2). ${ }^{49}$ These results thus suggest a reaction mechanism by coordination of phenols on the vanadium metal center (Scheme 2, shown in brackets) and not by protonation. It has also been assumed that

Received: February 25, 2019

Accepted: March 14, 2019

Published: March 25, 2019 
Scheme 1. Two Probable Pathways for Reaction of Metal Alkyl with Phenol (ArOH)

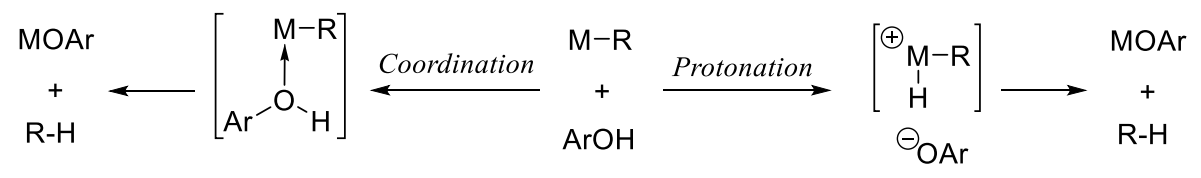

Scheme 2. Reactions of $\mathrm{V}\left(\mathrm{N}-2,6-\mathrm{Me}_{2} \mathrm{C}_{6} \mathrm{H}_{3}\right)\left(\mathrm{CH}_{2} \mathrm{SiMe}_{3}\right)_{3}$ with Phenols, Alcohols, ${ }^{48}$ and Fast Phenoxy Ligand Exchange in V(N2,6- $\left.\mathrm{Me}_{2} \mathrm{C}_{6} \mathrm{H}_{3}\right)\left(\mathrm{CH}_{2} \mathrm{SiMe}_{3}\right)_{2}\left(\mathrm{O}-2,6-\mathrm{Me}_{2} \mathrm{C}_{6} \mathrm{H}_{3}\right)^{49}$

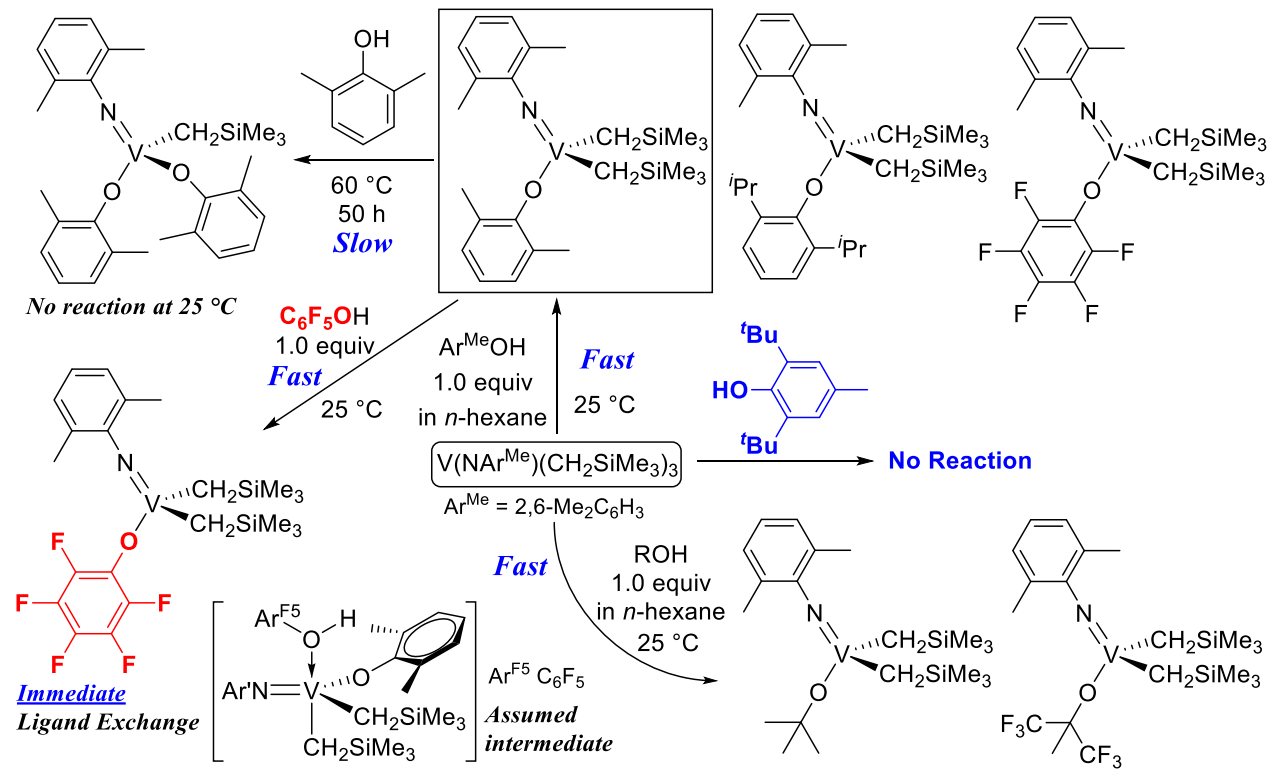

the reason for the negligible reactivity of $2,6-{ }^{t} \mathrm{Bu}_{2}-4-\mathrm{MeC}_{6} \mathrm{H}_{2} \mathrm{OH}$ could be due to a steric bulk of two tert-butyl groups and three $\mathrm{CH}_{2} \mathrm{SiMe}_{3}$ ligands that causes a difficulty of coordination of the phenol to vanadium. Similarly, the reaction of $\mathrm{V}\left(\mathrm{CHSiMe}_{3}\right)(\mathrm{N}$ 1-adamantyl $)\left(\mathrm{CH}_{2} \mathrm{SiMe}_{3}\right)\left(\mathrm{PMe}_{3}\right)_{2}$ with $\mathrm{C}_{6} \mathrm{~F}_{5} \mathrm{OH}$ became slow when $\mathrm{C}_{6} \mathrm{~F}_{5} \mathrm{OD}$ was used instead of $\mathrm{C}_{6} \mathrm{~F}_{5} \mathrm{OH}$ or in presence of $\mathrm{PMe}_{3} .{ }^{50}$ The results also suggest the mechanism by coordination of $\mathrm{C}_{6} \mathrm{~F}_{5} \mathrm{OH}$ accompanied by dissociation of $\mathrm{PMe}_{3}$. ${ }^{50,51}$ However, factors affecting the substitution rates (the electronic nature of phenol or vanadium metal center, steric bulk for coordination of phenol to vanadium, etc.) have still been unclear.

(Arylimido)vanadium(V)-alkylidene complexes containing phenoxide or alkoxide ligands have been known to display promising characteristics as catalysts for ring-opening metathesis polymerization of cyclic olefins (Scheme 3). ${ }^{42-44,48,50,52-55}$ These complexes are prepared from the corresponding dialkyl complexes by $\alpha$-hydrogen elimination in the presence of $\mathrm{PMe}_{3}$. The dialkyl complexes are prepared from the corresponding trialkyl complexes, $\mathrm{V}\left(\mathrm{NAr}^{\prime}\right)\left(\mathrm{CH}_{2} \mathrm{SiMe}_{3}\right)_{3}$, by treating with 1.0 equiv of phenol or alcohol.

In this study, reactions of a series of (arylimido)vanadium(V) trialkyl complexes, $\mathrm{V}\left(\mathrm{NAr}^{\prime}\right)\left(\mathrm{CH}_{2} \mathrm{SiMe}_{3}\right)_{3}\left(\mathrm{Ar}^{\prime}=\mathrm{C}_{6} \mathrm{H}_{5}\right.$, 2$\left.\mathrm{MeC}_{6} \mathrm{H}_{4}, 2,6-\mathrm{Me}_{2} \mathrm{C}_{6} \mathrm{H}_{3}, 2,6-\mathrm{Cl}_{2} \mathrm{C}_{6} \mathrm{H}_{3}\right)$, with various phenols, $\operatorname{ArOH}\left(\mathrm{Ar}=2,6-\mathrm{F}_{2} \mathrm{C}_{6} \mathrm{H}_{3}, 2,6-\mathrm{Cl}_{2} \mathrm{C}_{6} \mathrm{H}_{3}, 2,6-\mathrm{Me}_{2} \mathrm{C}_{6} \mathrm{H}_{3}\right.$, 2,6- ${ }_{-}^{i} \mathrm{Pr}_{2} \mathrm{C}_{6} \mathrm{H}_{3}, 2-{ }^{t} \mathrm{BuC}_{6} \mathrm{H}_{4}, 2,6-{ }^{t} \mathrm{Bu}_{2} \mathrm{C}_{6} \mathrm{H}_{3}$ ) have been conducted to explore factors (the electronic or steric nature of arylimido ligand or phenol) affecting the reaction rate for affording the phenoxide complexes, $\mathrm{V}\left(\mathrm{NAr}^{\prime}\right)\left(\mathrm{CH}_{2} \mathrm{SiMe}_{3}\right)_{2}$ (OAr) (Scheme 4), which have been prepared and identified independently. The results should provide important information for a better basic understanding of the reaction of high oxidation state early
Scheme 3. (Arylimido)vanadium(V)-Alkylidene Complexes as Effective Catalysts for Ring-Opening Metathesis Polymerization ${ }^{42-44,52-55}$
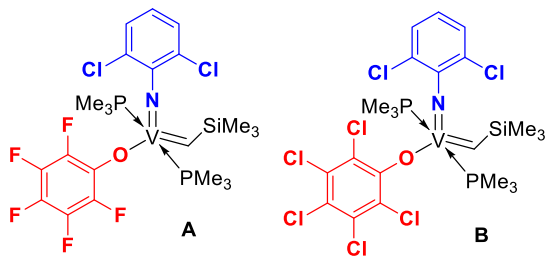

Highly active catalysts for ring-opening metathesis polymerization (ROMP) of cyclic olefins

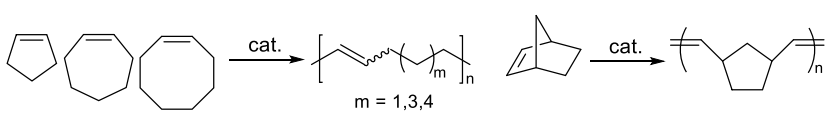

Scheme 4. Reactions of a Series of (Arylimido)vanadium(V)-Trialkyl Complexes with Different Phenols
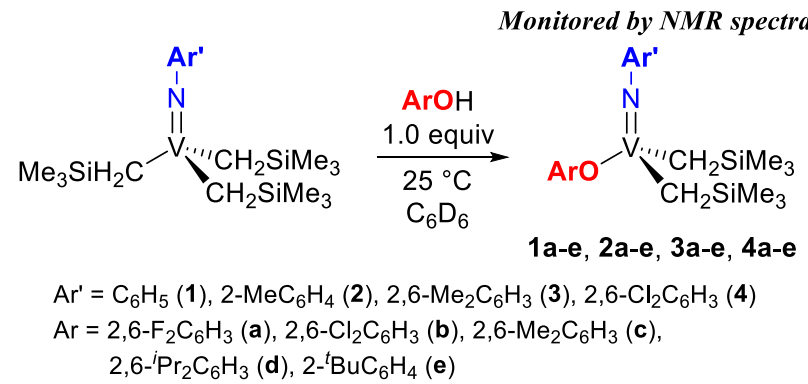

transition-metal-alkyls with phenol, which can be proposed to proceed via coordination of phenol to the metal center. ${ }^{48,49}$ 
Scheme 5. Synthesis of $\mathrm{V}\left(\mathrm{NAr}^{\prime}\right)\left(\mathrm{CH}_{2} \mathrm{SiMe}_{3}\right)_{2}(\mathrm{OAr})$ [ $1 \mathrm{a}-\mathrm{e}, \mathbf{2 a}-\mathrm{e}, 3 \mathrm{~b}, \mathrm{e}, 4 \mathrm{a}-\mathrm{e} ; \mathrm{Ar}^{\prime}=\mathrm{C}_{6} \mathrm{H}_{5}(1), 2-\mathrm{MeC}_{6} \mathrm{H}_{4}(2), 2,6-\mathrm{Me}_{2} \mathrm{C}_{6} \mathrm{H}_{3}(3)$, 2,6- $\mathrm{Cl}_{2} \mathrm{C}_{6} \mathrm{H}_{3}$ (4); $\mathrm{Ar}=2,6-\mathrm{F}_{2} \mathrm{C}_{6} \mathrm{H}_{3}$ (a), 2,6- $\mathrm{Cl}_{2} \mathrm{C}_{6} \mathrm{H}_{3}$ (b), 2,6- $-\mathrm{Me}_{2} \mathrm{C}_{6} \mathrm{H}_{3}$ (c), 2,6- ${ }^{i} \mathrm{Pr}_{2} \mathrm{C}_{6} \mathrm{H}_{3}$ (d), 2- $-{ }^{t} \mathrm{BuC}_{6} \mathrm{H}_{4}$ (e)], by reaction of $\mathrm{V}\left(\mathrm{NAr}^{\prime}\right)\left(\mathrm{CH}_{2} \mathrm{SiMe}_{3}\right)_{3}$ with 1.0 equiv of $\mathrm{ArOH}$
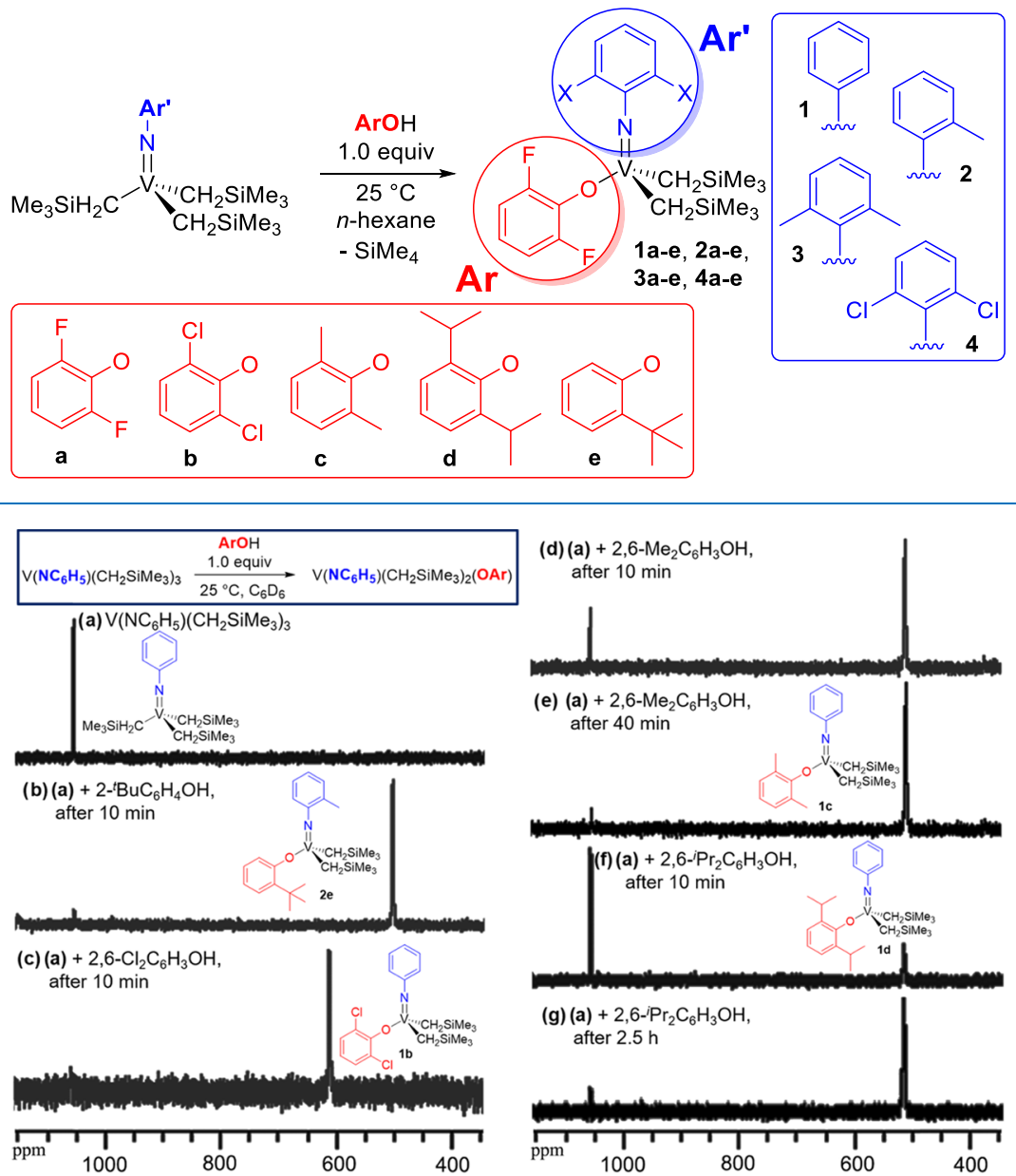

Figure 1. ${ }^{51} \mathrm{~V}$ NMR spectra (in $\mathrm{C}_{6} \mathrm{D}_{6}$ at $25^{\circ} \mathrm{C}$ ) for monitoring the reaction of $\mathrm{V}\left(\mathrm{NC}_{6} \mathrm{H}_{5}\right)\left(\mathrm{CH}_{2} \mathrm{SiMe}_{3}\right)_{3}$ with 1.0 equiv of $\mathrm{ArOH}\left(2-{ }^{t} \mathrm{BuC} \mathrm{C}_{6} \mathrm{H}_{4} \mathrm{OH}\right.$, 2,6$\left.\mathrm{Cl}_{2} \mathrm{C}_{6} \mathrm{H}_{3} \mathrm{OH}, 2,6-\mathrm{Me}_{2} \mathrm{C}_{6} \mathrm{H}_{3} \mathrm{OH}, 2,6-{ }^{i} \mathrm{Pr}_{2} \mathrm{C}_{6} \mathrm{H}_{3} \mathrm{OH}\right)$. Reaction of (a) $\mathrm{V}\left(\mathrm{NC}_{6} \mathrm{H}_{5}\right)\left(\mathrm{CH}_{2} \mathrm{SiMe}_{3}\right)_{3}$ with (b) 2- ${ }^{t} \mathrm{BuC}_{6} \mathrm{H}_{4} \mathrm{OH}$ (after 10 min, conv. 95\%), (c) 2,6- $\mathrm{Cl}_{2} \mathrm{C}_{6} \mathrm{H}_{3} \mathrm{OH}$ (after 10 min, conv. 92\%), (d) 2,6- $\mathrm{Me}_{2} \mathrm{C}_{6} \mathrm{H}_{3} \mathrm{OH}$ (after 10 min, conv. 82\%), (e) 2,6- $\mathrm{Me}_{2} \mathrm{C}_{6} \mathrm{H}_{3} \mathrm{OH}$ (after 40 min, conv. 95\%), (f) 2,6- ${ }^{i} \mathrm{Pr}_{2} \mathrm{C}_{6} \mathrm{H}_{3} \mathrm{OH}$ (after $10 \mathrm{~min}$, conv. 34\%), and (g) 2,6 ${ }_{-}^{i} \mathrm{Pr}_{2} \mathrm{C}_{6} \mathrm{H}_{3} \mathrm{OH}$ (after $2.5 \mathrm{~h}$, conv. 94\%). The conversions (conv.) were estimated on the basis of integration ratios of dialkyl/trialkyl complexes in the ${ }^{51} \mathrm{~V}$ NMR spectra (except in the reaction with 2,6- $\mathrm{Cl}_{2} \mathrm{C}_{6} \mathrm{H}_{3} \mathrm{OH}$ ). ${ }^{b}$

\section{RESULTS AND DISCUSSION}

Synthesis of (Arylimido)vanadium(V)-Dialkyl Complexes Containing Phenoxide Ligands, V(NAr')$\left(\mathrm{CH}_{2} \mathrm{SiMe}_{3}\right)_{2}(\mathrm{OAr})$. A series of (arylimido)vanadium $(\mathrm{V})-$ dialkyl complexes containing phenoxide ligands, $\mathrm{V}\left(\mathrm{NAr}^{\prime}\right)$ $\left(\mathrm{CH}_{2} \mathrm{SiMe}_{3}\right)_{2}(\mathrm{OAr})\left[\mathbf{1 a}-\mathbf{e}, \mathbf{2} \mathbf{a}-\mathbf{e}, \mathbf{3 b}, \mathbf{e}, \mathbf{4 a}-\mathbf{a} ; \mathrm{Ar}^{\prime}=\mathrm{C}_{6} \mathrm{H}_{5}\right.$ (1), 2- $\mathrm{MeC}_{6} \mathrm{H}_{4}$ (2), 2,6- $\mathrm{Me}_{2} \mathrm{C}_{6} \mathrm{H}_{3}$ (3), 2,6- $\mathrm{Cl}_{2} \mathrm{C}_{6} \mathrm{H}_{3}$ (4); $\mathrm{Ar}=$ 2,6- $\mathrm{F}_{2} \mathrm{C}_{6} \mathrm{H}_{3}$ (a), 2,6- $\mathrm{Cl}_{2} \mathrm{C}_{6} \mathrm{H}_{3}$ (b), 2,6- $\mathrm{Me}_{2} \mathrm{C}_{6} \mathrm{H}_{3}$ (c), 2,6- ${ }^{i} \mathrm{Pr}_{2} \mathrm{C}_{6} \mathrm{H}_{3}$ (d), $2-{ }^{t} \mathrm{BuC}_{6} \mathrm{H}_{4}$ (e)], could be prepared from $\mathrm{V}\left(\mathrm{NAr}^{\prime}\right)\left(\mathrm{CH}_{2} \mathrm{SiMe}_{3}\right)_{3}$ by treating with 1.0 equiv of $\mathrm{ArOH}$ in $n-$ hexane at -30 to $25^{\circ} \mathrm{C}$ (Scheme 5, synthetic details are shown in the Experimental Section). These synthetic procedures are analogous to those reported previously for syntheses of $\mathbf{3 a , c , d},{ }^{48,49}$ and the resultant complexes were identified by NMR spectra (shown in the Supporting Information, $\mathrm{SI})^{a}$ and elemental analysis (except for $\mathbf{3 b}, \mathbf{4 d}$, and $\mathbf{4 e})$. Structure of $\mathrm{V}(\mathrm{N}$ 2,6- $\left.\mathrm{Cl}_{2} \mathrm{C}_{6} \mathrm{H}_{3}\right)\left(\mathrm{CH}_{2} \mathrm{SiMe}_{3}\right)_{2}\left(\mathrm{O}-2,6-{ }^{i} \mathrm{Pr}_{2} \mathrm{C}_{6} \mathrm{H}_{3}\right)$ (4d) was also confirmed by $\mathrm{X}$-ray crystallography (detailed analysis and selected bond distances and angles are shown in the SI). ${ }^{a}$ Complex $4 \mathrm{~d}$ holds a distorted tetrahedral geometry around vanadium, and the $\mathrm{V}-\mathrm{N}-\mathrm{C}$ (phenyl) bond angle $\left[167.59(11)^{\circ}\right]$ is relatively close to that of $\mathrm{V}\left(\mathrm{N}-2,6-{ }^{i} \mathrm{Pr}_{2} \mathrm{C}_{6} \mathrm{H}_{3}\right)\left(\mathrm{CH}_{2} \mathrm{Ph}\right)_{3}[5$, $\left.169.0(5)^{\circ}\right]^{32}$ but is larger than that of $\mathrm{V}\left(\mathrm{N}-2,6-{ }^{i} \mathrm{Pr}_{2} \mathrm{C}_{6} \mathrm{H}_{3}\right)$ $\left(\mathrm{CH}_{2} \mathrm{Ph}\right)_{2}\left(\mathrm{O}-2,6-{ }^{i} \mathrm{Pr}_{2} \mathrm{C}_{6} \mathrm{H}_{3}\right)\left[6,161.7(4)^{\circ}\right] ;^{32}$ the angle is however smaller than that in $\mathrm{V}(\mathrm{N}$-1-adamantyl $)\left(\mathrm{CH}_{2} \mathrm{SiMe}_{3}\right)_{3}$ $\left[7,180.00(17)^{\circ}\right] .{ }^{a}$ The $\mathrm{V}-\mathrm{N}$ bond distance $[1.6627(16) \AA]$ is close to that in $\mathbf{6}[1.669(5) \AA]^{32}$ but longer than that in 5 and 7 $\left[1.641(6), 1.6317(14) \AA\right.$, respectively]., ${ }^{32 a}$ The $\mathrm{V}-\mathrm{O}$ bond distance in $4 \mathrm{~d}[1.7662(12) \AA]$ is slightly longer than that in 6 $[1.746(4) \AA],,^{32}$ and the $\mathrm{V}-\mathrm{C}$ bond distance $[2.0269(19)$, $2.019(2) \AA]$ is shorter than that in 5 and $6[2.048(7)-2.086(8)$ $\AA]^{32}$ but close to that in complex 7 [2.0267(18) $\left.\AA\right]^{a}$

In contrast, as described below, attempted reactions of $\mathrm{V}\left(\mathrm{NAr}^{\prime}\right)\left(\mathrm{CH}_{2} \mathrm{SiMe}_{3}\right)_{3}\left(\mathrm{Ar}^{\prime}=\mathrm{C}_{6} \mathrm{H}_{5}, 2-\mathrm{MeC}_{6} \mathrm{H}_{4}, 2,6-\mathrm{Me}_{2} \mathrm{C}_{6} \mathrm{H}_{3}\right.$, 2,6- $\left.\mathrm{Cl}_{2} \mathrm{C}_{6} \mathrm{H}_{3}\right)$ with 3.0 equiv of $2,6{ }^{-}{ }^{-} \mathrm{Bu}_{2} \mathrm{C}_{6} \mathrm{H}_{3} \mathrm{OH}$ in $\mathrm{C}_{6} \mathrm{D}_{6}$ at 25 ${ }^{\circ} \mathrm{C}$ recovered the trialkyl complexes (data are shown in the SI), ${ }^{b}$ as reported in the reaction of $\mathrm{V}\left(\mathrm{N}-2,6-\mathrm{Me}_{2} \mathrm{C}_{6} \mathrm{H}_{3}\right)\left(\mathrm{CH}_{2} \mathrm{SiMe}_{3}\right)_{3}$ with 2,6- ${ }^{t} \mathrm{Bu}_{2}-4-\mathrm{MeC}_{6} \mathrm{H}_{2} \mathrm{OH}$. ${ }^{48}$

NMR Study for Monitoring Reactions of (Arylimido)vanadium(V)-Trialkyl Complexes, V(NAr') $\left(\mathrm{CH}_{2} \mathrm{SiMe}_{3}\right)_{3 \prime}$ with Phenols (ArOH). Reactions of a series of (arylimido)- 

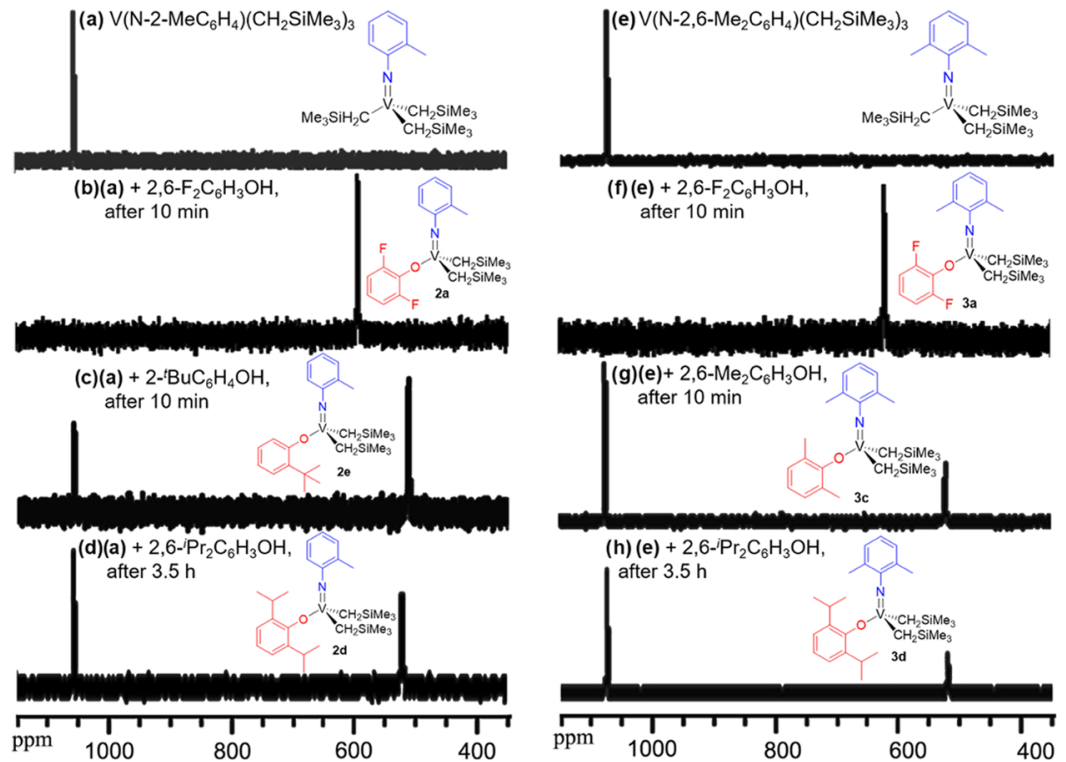

Figure 2. ${ }^{51} \mathrm{~V}$ NMR spectra (in $\mathrm{C}_{6} \mathrm{D}_{6}$ at $25{ }^{\circ} \mathrm{C}$ ) for monitoring the reaction of $\mathrm{V}\left(\mathrm{NAr}^{\prime}\right)\left(\mathrm{CH}_{2} \mathrm{SiMe}_{3}\right)_{3}$ with phenols. Reactions of (a) $\mathrm{V}(\mathrm{N}-2$ $\left.\mathrm{MeC}_{6} \mathrm{H}_{4}\right)\left(\mathrm{CH}_{2} \mathrm{SiMe}_{3}\right)_{3}$ with 1.0 equiv of (b) 2,6- $\mathrm{F}_{2} \mathrm{C}_{6} \mathrm{H}_{3} \mathrm{OH}$ (after 10 min, conv. >99\%), (c) $2-{ }^{t} \mathrm{BuC}_{6} \mathrm{H}_{4} \mathrm{OH}$ (after 10 min, conv. $74 \%$ ), and (d) 2,6- ${ }^{i} \mathrm{Pr}_{2} \mathrm{C}_{6} \mathrm{H}_{3} \mathrm{OH}$ (after $3.5 \mathrm{~h}$, conv. 63\%). Reactions of (e) V(N-2,6- $\left.\mathrm{Me}_{2} \mathrm{C}_{6} \mathrm{H}_{3}\right)\left(\mathrm{CH}_{2} \mathrm{SiMe}_{3}\right)_{3}$ with (f) 2,6- $\mathrm{F}_{2} \mathrm{C}_{6} \mathrm{H}_{3} \mathrm{OH}$ (after 10 min, conv. >99\%), (g) 2,6- $\mathrm{Me}_{2} \mathrm{C}_{6} \mathrm{H}_{3} \mathrm{OH}$ (after $10 \mathrm{~min}$, conv. 37\%), and (h) 2,6- ${ }^{i} \mathrm{Pr}_{2} \mathrm{C}_{6} \mathrm{H}_{3} \mathrm{OH}$ (after $3.5 \mathrm{~h}$, conv. 34\%). The conversions were estimated on the basis of integration ratios of dialkyl/trialkyl complexes in the ${ }^{51} \mathrm{~V}$ NMR spectra. ${ }^{b}$

vanadium $(\mathrm{V})$ trialkyl complexes, $\mathrm{V}\left(\mathrm{NAr}^{\prime}\right)\left(\mathrm{CH}_{2} \mathrm{SiMe}_{3}\right)_{3}\left(\mathrm{Ar}^{\prime}=\right.$ $\left.\mathrm{C}_{6} \mathrm{H}_{5}, 2-\mathrm{MeC}_{6} \mathrm{H}_{4}, 2,6-\mathrm{Me}_{2} \mathrm{C}_{6} \mathrm{H}_{3}, 2,6-\mathrm{Cl}_{2} \mathrm{C}_{6} \mathrm{H}_{3}\right)$, with 1.0 equiv of phenols ( $\mathrm{ArOH}, \mathrm{Ar}=2,6-\mathrm{F}_{2} \mathrm{C}_{6} \mathrm{H}_{3}, 2,6-\mathrm{Cl}_{2} \mathrm{C}_{6} \mathrm{H}_{3}, 2,6-\mathrm{Me}_{2} \mathrm{C}_{6} \mathrm{H}_{3}$, $\left.2,6-{ }^{i} \mathrm{Pr}_{2} \mathrm{C}_{6} \mathrm{H}_{3}, 2-{ }^{t} \mathrm{BuC}_{6} \mathrm{H}_{4}, 2,6-{ }^{t} \mathrm{Bu}_{2} \mathrm{C}_{6} \mathrm{H}_{3}\right)$ were conducted in $\mathrm{C}_{6} \mathrm{D}_{6}$ at $25{ }^{\circ} \mathrm{C}$, and the time profiles were monitored by ${ }^{51} \mathrm{~V}$ and ${ }^{1} \mathrm{H}$ NMR spectra after addition of 1.0 equiv of $\mathrm{ArOH}$ (in $\mathrm{C}_{6} \mathrm{D}_{6}$, ca. $0.4 \mathrm{~mL}$ ) into a $\mathrm{C}_{6} \mathrm{D}_{6}$ solution containing the trialkyl complex $(50 \mu \mathrm{mol}$ in ca. $0.6 \mathrm{~mL}) .^{b}$ The conversions of $\mathrm{V}\left(\mathrm{NAr}^{\prime}\right)$ $\left(\mathrm{CH}_{2} \mathrm{SiMe}_{3}\right)_{3}$ were estimated by the integration ratio (between the trialkyl and dialkyl complexes) in the ${ }^{51}$ V NMR spectra; the ratios in the ${ }^{1} \mathrm{H}$ NMR spectra were used for confirmation (all spectra are shown in the SI). ${ }^{b}$ In reactions using 2,6$\mathrm{Cl}_{2} \mathrm{C}_{6} \mathrm{H}_{3} \mathrm{OH}$, the conversions were estimated from ${ }^{1} \mathrm{H}$ NMR spectra as a better resolution was observed. ${ }^{b}$ The selected ${ }^{51} \mathrm{~V}$ NMR spectra are summarized in Figures 1 and $2 .^{b}$

It turned out that the reaction of $\mathrm{V}\left(\mathrm{NC}_{6} \mathrm{H}_{5}\right)\left(\mathrm{CH}_{2} \mathrm{SiMe}_{3}\right)_{3}$ (Figure 1a) with 2,6- $\mathrm{Cl}_{2} \mathrm{C}_{6} \mathrm{H}_{3} \mathrm{OH}$ (1.0 equiv) completed within $40 \mathrm{~min}$ [conversion of the trialkyl complex (conv.) $=92 \%$ after $10 \mathrm{~min}$ (Figure 1c) and $>99 \%$ after $40 \mathrm{~min}$ (Figure S2-2)] to afford $\mathrm{V}\left(\mathrm{NC}_{6} \mathrm{H}_{5}\right)\left(\mathrm{CH}_{2} \mathrm{SiMe}_{3}\right)_{2}\left(\mathrm{O}-2,6-\mathrm{Cl}_{2} \mathrm{C}_{6} \mathrm{H}_{3}\right)(\mathbf{1 b})^{b}$ and the reaction with $2-{ }^{t} \mathrm{BuC}_{6} \mathrm{H}_{4} \mathrm{OH}$ also completed within $40 \mathrm{~min}$ [conv. 95\% after $10 \mathrm{~min}$ (Figure 1b), >99\% after $40 \mathrm{~min}$ (Figure S2-5)]. The reaction with 2,6- $\mathrm{F}_{2} \mathrm{C}_{6} \mathrm{H}_{3} \mathrm{OH}$ completed within 10 min to afford $\mathrm{V}\left(\mathrm{NC}_{6} \mathrm{H}_{5}\right)\left(\mathrm{CH}_{2} \mathrm{SiMe}_{3}\right)_{2}\left(\mathrm{O}-2,6-\mathrm{F}_{2} \mathrm{C}_{6} \mathrm{H}_{3}\right)$ (1a, Figure S2-1). ${ }^{b}$ In contrast, the conversions in the reaction with 2,6- $\mathrm{Me}_{2} \mathrm{C}_{6} \mathrm{H}_{3} \mathrm{OH}$ became slightly low [conv. 82\% after $10 \mathrm{~min}$ (Figure 1d), and 95\% after $40 \mathrm{~min}$ (Figures $1 \mathrm{e}$ and $\mathrm{S} 2-3$ ) $]^{b}$ and the reaction with $2,6-{ }^{i} \mathrm{Pr}_{2} \mathrm{C}_{6} \mathrm{H}_{3} \mathrm{OH}$ proceeded slowly compared with the other phenols [conv. 34\% after $10 \mathrm{~min}$ (Figure 1f), 61\% after $40 \mathrm{~min}$ (Figure S2-4), 94\% after $2.5 \mathrm{~h}$ (Figure $1 \mathrm{~g}$ )]. Moreover, the reaction with $2,6-{ }^{t} \mathrm{Bu}_{2} \mathrm{C}_{6} \mathrm{H}_{3} \mathrm{OH}$ (3.0 equiv) at 25 ${ }^{\circ} \mathrm{C}$ did not take place even after 6 days (confirmed by ${ }^{1} \mathrm{H}$ and ${ }^{51} \mathrm{~V}$ NMR spectra, Figure S2-22). ${ }^{b}$ No additional new resonances in the ${ }^{51} \mathrm{~V}$ NMR spectra were observed when the mixture in the reaction with 1.0 equiv of $2,6-{ }^{t} \mathrm{Bu}_{2} \mathrm{C}_{6} \mathrm{H}_{3} \mathrm{OH}$ was heated at $60^{\circ} \mathrm{C}$ for $50 \mathrm{~h}$ after stirring at $25{ }^{\circ} \mathrm{C}$ for 4 days (no significant changes were observed upon heating in the ${ }^{1} \mathrm{H}$ NMR spectra, Figure S2-
21). ${ }^{b}$ Therefore, the substitution rates with 1.0 equiv of $\mathrm{ArOH}$ increased in the order: $\mathrm{Ar}=2,6-{ }^{t} \mathrm{Bu}_{2} \mathrm{C}_{6} \mathrm{H}_{3} \ll 2,6-{ }^{i} \mathrm{Pr}_{2} \mathrm{C}_{6} \mathrm{H}_{3}<2,6-$ $\mathrm{Me}_{2} \mathrm{C}_{6} \mathrm{H}_{3}<2,6-\mathrm{Cl}_{2} \mathrm{C}_{6} \mathrm{H}_{3}, 2-{ }^{t} \mathrm{BuC}_{6} \mathrm{H}_{4}<2,6-\mathrm{F}_{2} \mathrm{C}_{6} \mathrm{H}_{3}$ (Scheme 6). Similarly, as shown in Scheme 6 (and in part in Figure 2), ${ }^{b}$ the conversions in the reaction of $\mathrm{V}\left(\mathrm{N}-2,6-\mathrm{Me}_{2} \mathrm{C}_{6} \mathrm{H}_{3}\right)\left(\mathrm{CH}_{2} \mathrm{SiMe}_{3}\right)_{3}$ with 1.0 equiv of $\mathrm{ArOH}$ increased in the order: $\mathrm{Ar}=$ $2,6-{ }^{t} \mathrm{Bu}_{2} \mathrm{C}_{6} \mathrm{H}_{3}$ (negligible after 6 days, Figure S2-26) $\ll$ $2,6-{ }^{i} \operatorname{Pr}_{2} \mathrm{C}_{6} \mathrm{H}_{3}$ (34\% conversion after $3.5 \mathrm{~h}$, Figure $\left.2 \mathrm{~h}\right)<2,6$ -

Scheme 6. Reactions of $\mathrm{V}\left(\mathrm{NC}_{6} \mathrm{H}_{5}\right)\left(\mathrm{CH}_{2} \mathrm{SiMe}_{3}\right)_{3}$ and $\mathrm{V}(\mathrm{N}$ 2,6- $\left.\mathrm{Me}_{2} \mathrm{C}_{6} \mathrm{H}_{3}\right)\left(\mathrm{CH}_{2} \mathrm{SiMe}_{3}\right)_{3}$ with 1.0 equiv of $\mathrm{ArOH}(\mathrm{Ar}=$ 2,6- $\mathrm{F}_{2} \mathrm{C}_{6} \mathrm{H}_{3}, 2,6-\mathrm{Cl}_{2} \mathrm{C}_{6} \mathrm{H}_{3}, 2,6-\mathrm{Me}_{2} \mathrm{C}_{6} \mathrm{H}_{3}, 2,6-{ }^{i} \mathrm{Pr}_{2} \mathrm{C}_{6} \mathrm{H}_{3}$, $\left.2-{ }_{-}^{t} \mathrm{BuC}_{6} \mathrm{H}_{4}, 2,6-{ }^{t} \mathrm{Bu}_{2} \mathrm{C}_{6} \mathrm{H}_{3}\right)$ in $\mathrm{C}_{6} \mathrm{D}_{6}$ at $25{ }^{\circ} \mathrm{C}$

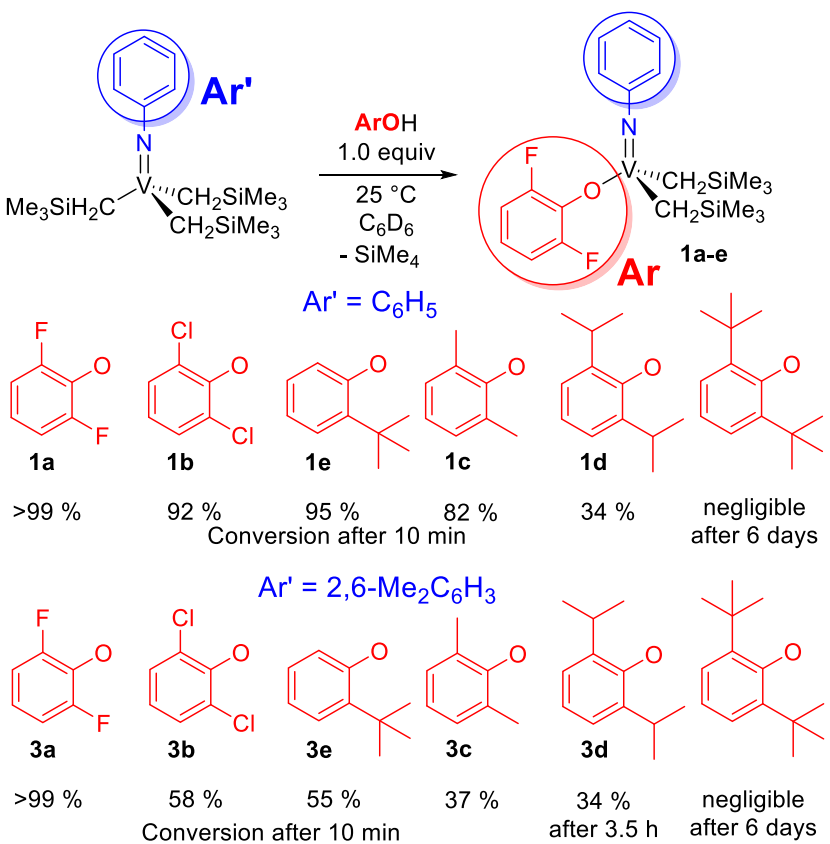


Table 1. Reactions of $\mathrm{V}\left(\mathrm{NAr}^{\prime}\right)\left(\mathrm{CH}_{2} \mathrm{SiMe}_{3}\right)_{3}\left(\mathrm{Ar}^{\prime}=\mathrm{C}_{6} \mathrm{H}_{5}, 2-\mathrm{MeC}_{6} \mathrm{H}_{4}, 2,6-\mathrm{Me}_{2} \mathrm{C}_{6} \mathrm{H}_{3}, 2,6-\mathrm{Cl}_{2} \mathrm{C}_{6} \mathrm{H}_{3}\right)$, with 1.0 equiv of Various $\operatorname{ArOH}\left(\mathrm{Ar}=2,6-\mathrm{F}_{2} \mathrm{C}_{6} \mathrm{H}_{3}, 2,6-\mathrm{Cl}_{2} \mathrm{C}_{6} \mathrm{H}_{3}, 2,6-\mathrm{Me}_{2} \mathrm{C}_{6} \mathrm{H}_{3}, 2,6-{ }^{i} \mathrm{Pr}_{2} \mathrm{C}_{6} \mathrm{H}_{3},{ }^{2}-{ }^{t} \mathrm{BuC}_{6} \mathrm{H}_{4}, 2,6-{ }^{t} \mathrm{Bu}_{2} \mathrm{C}_{6} \mathrm{H}_{3}\right)$ in $\mathrm{C}_{6} \mathrm{D}_{6}$ at $25{ }^{\circ} \mathrm{C}^{a}$

\begin{tabular}{|c|c|c|c|c|}
\hline \multirow[b]{2}{*}{$\mathrm{Ar}^{\prime}$} & \multicolumn{4}{|c|}{ conversion (\%) in the reaction of $\mathrm{V}\left(\mathrm{NAr}^{\prime}\right)\left(\mathrm{CH}_{2} \mathrm{SiMe}_{3}\right)_{3}$ with $\mathrm{ArOH}^{b}$} \\
\hline & $\mathrm{C}_{6} \mathrm{H}_{5}$ & $2-\mathrm{MeC}_{6} \mathrm{H}_{4}$ & $2,6-\mathrm{Me}_{2} \mathrm{C}_{6} \mathrm{H}_{3}$ & $2,6-\mathrm{Cl}_{2} \mathrm{C}_{6} \mathrm{H}_{3}$ \\
\hline$\delta(\mathrm{ppm})$ in ${ }^{51} \mathrm{~V} \mathrm{NMR}^{c}$ & 1052.2 & 1059.4 & 1162.3 & 1076.4 \\
\hline $2,6-\mathrm{F}_{2} \mathrm{C}_{6} \mathrm{H}_{3} \mathrm{OH}$ & $>99 \%(>99 \%)^{d}$ & $>99 \%(>99 \%)^{d}$ & $>99 \%(>99 \%)^{d}$ & $>99 \%(>99 \%)^{d}$ \\
\hline $2,6-\mathrm{Cl}_{2} \mathrm{C}_{6} \mathrm{H}_{3} \mathrm{OH}$ & $92 \%^{e}(\gg 99 \%)^{d, e}$ & $86 \%^{e}(>99 \%)^{d, e}$ & $58 \%^{e}(73 \%)^{d, e}$ & $74 \%^{e}(87 \%)^{d, e}$ \\
\hline $2,6-\mathrm{Me}_{2} \mathrm{C}_{6} \mathrm{H}_{3} \mathrm{OH}$ & $82 \%(95 \%)^{d}$ & $76 \%(97 \%)^{d}$ & $37 \%(66 \%)^{d}$ & $67 \%(88 \%)^{d}$ \\
\hline $2,6-{ }^{i} \mathrm{Pr}_{2} \mathrm{C}_{6} \mathrm{H}_{3} \mathrm{OH}$ & $34 \%(61 \%)^{d}$ & $14 \%(25 \%)^{d}$ & $\operatorname{trace}(8 \%)^{d}$ & $10 \%(19 \%)^{d}$ \\
\hline $2-{ }^{t} \mathrm{BuC}_{6} \mathrm{H}_{4} \mathrm{OH}$ & $95 \%(>99 \%)^{d}$ & $74 \%(89 \%)^{d}$ & $55 \%(76 \%)^{d}$ & $73 \%(86 \%)^{d}$ \\
\hline $2,6-{ }^{t} \mathrm{Bu}_{2} \mathrm{C}_{6} \mathrm{H}_{3} \mathrm{OH}$ & negligible & negligible & negligible & negligible \\
\hline
\end{tabular}

${ }^{a}$ Conditions: $\mathrm{V}\left(\mathrm{NAr}^{\prime}\right)\left(\mathrm{CH}_{2} \mathrm{SiMe}_{3}\right)_{3} 50 \mu \mathrm{mol}$ in $\mathrm{C}_{6} \mathrm{D}_{6}$ (total $\left.1.0 \mathrm{~mL}\right), 25{ }^{\circ} \mathrm{C} .{ }^{b}$ Conversion (\%) after 10 min estimated by the integration ratio of $\mathrm{V}\left(\mathrm{NAr}^{\prime}\right)\left(\mathrm{CH}_{2} \mathrm{SiMe}_{3}\right)_{2}(\mathrm{OAr}) / \mathrm{V}\left(\mathrm{NAr}^{\prime}\right)\left(\mathrm{CH}_{2} \mathrm{SiMe}_{3}\right)_{3}$ by ${ }^{51} \mathrm{~V}$ NMR spectra. ${ }^{c}$ Chemical shifts $\left(\right.$ in $\left.\mathrm{C}_{6} \mathrm{D}_{6}\right)$ for $\mathrm{V}\left(\mathrm{NAr}^{\prime}\right)\left(\mathrm{CH}_{2} \mathrm{SiMe}_{3}\right)_{3}$ in ${ }^{51} \mathrm{~V} \mathrm{NMR}$ spectra. ${ }^{d}$ Conversion (\%) after 40 min estimated by ${ }^{51} \mathrm{~V}$ NMR spectra. ${ }^{e}$ Conversion (\%) estimated by ${ }^{1} \mathrm{H}$ NMR spectra. Detailed data are shown in the Supporting Information.

$\mathrm{Me}_{2} \mathrm{C}_{6} \mathrm{H}_{3}$ (37\% conversion after $10 \mathrm{~min}$, Figure $\left.2 \mathrm{~g}\right)<2,6-$ $\mathrm{Cl}_{2} \mathrm{C}_{6} \mathrm{H}_{3}$ (58\% after $10 \mathrm{~min}$, Figure $\left.\mathrm{S} 2-12\right), 2-{ }^{t} \mathrm{BuC}_{6} \mathrm{H}_{4}(55 \%$, after $10 \mathrm{~min}$, Figure $\mathrm{S} 2-15)<2,6-\mathrm{F}_{2} \mathrm{C}_{6} \mathrm{H}_{3}(>99 \%$ after $10 \mathrm{~min}$, Figure $2 \mathrm{f}$ ). These results clearly suggest that the substitution rate decreased with increasing the steric bulk in the phenolic orthosubstituents.

Table 1 summarizes the results in the reaction of $\mathrm{V}\left(\mathrm{NAr}^{\prime}\right)$ $\left(\mathrm{CH}_{2} \mathrm{SiMe}_{3}\right)_{3}$ with $\mathrm{ArOH}$ (1.0 equiv) in $\mathrm{C}_{6} \mathrm{D}_{6}$ at $25^{\circ} \mathrm{C}^{\circ} \mathrm{A}$ similar trend shown in Scheme 6 was observed in the reaction of $\mathrm{V}\left(\mathrm{N}-2,6-\mathrm{Cl}_{2} \mathrm{C}_{6} \mathrm{H}_{3}\right)\left(\mathrm{CH}_{2} \mathrm{SiMe}_{3}\right)_{3}$. Moreover, as also shown in part in Figure 2, the rates in the reaction of $\mathrm{V}(\mathrm{N}-2$ $\left.\mathrm{MeC}_{6} \mathrm{H}_{4}\right)\left(\mathrm{CH}_{2} \mathrm{SiMe}_{3}\right)_{3}$ with $\mathrm{ArOH}$ (1.0 equiv) increased in the order: $\mathrm{Ar}=2,6-{ }^{t} \mathrm{Bu}_{2} \mathrm{C}_{6} \mathrm{H}_{3} \ll 2,6-{ }^{i} \mathrm{Pr}_{2} \mathrm{C}_{6} \mathrm{H}_{3}<2,6-\mathrm{Me}_{2} \mathrm{C}_{6} \mathrm{H}_{3}$, 2- ${ }^{t} \mathrm{BuC}_{6} \mathrm{H}_{4}<2,6-\mathrm{Cl}_{2} \mathrm{C}_{6} \mathrm{H}_{3}<2,6-\mathrm{F}_{2} \mathrm{C}_{6} \mathrm{H}_{3}$; the degree in the reaction with $2-{ }^{t} \mathrm{BuC}_{6} \mathrm{H}_{4} \mathrm{OH}$ was close to that in the reaction with 2,6- $\mathrm{Me}_{2} \mathrm{C}_{6} \mathrm{H}_{3} \mathrm{OH}$.

To estimate the electronic nature in $\mathrm{ArOH}, \mathrm{pK}$ a values (in aqueous solution) in the disubstituted phenols ${ }^{57-59}$ have been chosen, although these reactions were conducted in $\mathrm{C}_{6} \mathrm{D}_{6}$ (or $n$ hexane for isolation). It turned out that the observed orders on the substitution rates are somewhat different from the $\mathrm{p} K_{\mathrm{a}}$ values: $2,6-\mathrm{Cl}_{2} \mathrm{C}_{6} \mathrm{H}_{3} \mathrm{OH}\left(\mathrm{pK}_{\mathrm{a}}=6.79\right)^{57} 2,6-\mathrm{F}_{2} \mathrm{C}_{6} \mathrm{H}_{3} \mathrm{OH}(7.58)^{58}$ $<2,6-\mathrm{Me}_{2} \mathrm{C}_{6} \mathrm{H}_{3} \mathrm{OH}(10.59)^{57}<2,6-{ }^{i} \mathrm{Pr}_{2} \mathrm{C}_{6} \mathrm{H}_{3} \mathrm{OH}$ (11.1). ${ }^{59}$ In fact, the reaction of $\mathrm{V}\left(\mathrm{N}-2,6-\mathrm{Me}_{2} \mathrm{C}_{6} \mathrm{H}_{3}\right)\left(\mathrm{CH}_{2} \mathrm{SiMe}_{3}\right)_{3}$ with 1.0 equiv of $\mathrm{PhOH}\left(\mathrm{p} K_{\mathrm{a}}=9.99\right)^{57}$ completed within $10 \mathrm{~min}$ to afford $\mathrm{V}\left(\mathrm{N}-2,6-\mathrm{Me}_{2} \mathrm{C}_{6} \mathrm{H}_{3}\right)\left(\mathrm{CH}_{2} \mathrm{SiMe}_{3}\right)_{2}(\mathrm{OPh})^{b}$ (data are shown in the SI, Figure S2-29). ${ }^{b}$ It also turned out that the phenylimido complex showed higher conversions than the other arylimido complexes and the degree increased in the order: $\mathrm{Ar}^{\prime}=$ 2,6- $-\mathrm{Me}_{2} \mathrm{C}_{6} \mathrm{H}_{3}<2,6-\mathrm{Cl}_{2} \mathrm{C}_{6} \mathrm{H}_{3}<2-\mathrm{MeC}_{6} \mathrm{H}_{4}<\mathrm{C}_{6} \mathrm{H}_{5}$. The observed trend is somewhat different from that on the basis of chemical shifts in the ${ }^{51} \mathrm{~V}$ NMR spectra, which could be related to the nucleophilic nature in the (arylimido)vanadium complexes (Table 1). ${ }^{60}$ Taking into account these results, as described above, it is clear that the steric bulk in $\mathrm{ArOH}$ plays a role in the substitution rate.

\section{CONCLUDING REMARKS}

We have conducted reactions of various (arylimido)vanadium(V)-trialkyl complexes, $\mathrm{V}\left(\mathrm{NAr}^{\prime}\right)\left(\mathrm{CH}_{2} \mathrm{SiMe}_{3}\right)_{3}\left(\mathrm{Ar}^{\prime}=\mathrm{C}_{6} \mathrm{H}_{5}, 2\right.$ $\mathrm{MeC}_{6} \mathrm{H}_{4}, 2,6-\mathrm{Me}_{2} \mathrm{C}_{6} \mathrm{H}_{3}, 2,6-\mathrm{Cl}_{2} \mathrm{C}_{6} \mathrm{H}_{3}$ ), with 1.0 equiv of phenols ( $\mathrm{ArOH}, \mathrm{Ar}=2,6-\mathrm{F}_{2} \mathrm{C}_{6} \mathrm{H}_{3}, 2,6-\mathrm{Cl}_{2} \mathrm{C}_{6} \mathrm{H}_{3}, 2,6-\mathrm{Me}_{2} \mathrm{C}_{6} \mathrm{H}_{3}$, 2,6- $\left.{ }^{i} \mathrm{Pr}_{2} \mathrm{C}_{6} \mathrm{H}_{3}, 2-{ }^{t} \mathrm{BuC}_{6} \mathrm{H}_{4}, 2,6-{ }^{t} \mathrm{Bu}_{2} \mathrm{C}_{6} \mathrm{H}_{3}\right)$ in $\mathrm{C}_{6} \mathrm{D}_{6}$ at $25{ }^{\circ} \mathrm{C}$ and explored effects of both arylimido ligand and phenol on the substitution rate. The phenylimido complex showed the highest conversions, and the degree increased in the order: $\mathrm{Ar}^{\prime}=2,6-$
$\mathrm{Me}_{2} \mathrm{C}_{6} \mathrm{H}_{3}<2,6-\mathrm{Cl}_{2} \mathrm{C}_{6} \mathrm{H}_{3}<2-\mathrm{MeC}_{6} \mathrm{H}_{4}<\mathrm{C}_{6} \mathrm{H}_{5}$. The order is somewhat different from that obtained from the chemical shifts in $\mathrm{V}\left(\mathrm{NAr}^{\prime}\right)\left(\mathrm{CH}_{2} \mathrm{SiMe}_{3}\right)_{3}$ in the ${ }^{51} \mathrm{~V} \mathrm{NMR}$ spectra. Moreover, conversions in the reaction of $\mathrm{V}\left(\mathrm{NAr}^{\prime}\right)\left(\mathrm{CH}_{2} \mathrm{SiMe}_{3}\right)_{3}$ with disubstituted phenols increased in the order: $2,6-{ }^{-} \mathrm{Pr}_{2} \mathrm{C}_{6} \mathrm{H}_{3} \mathrm{OH}<$ $2,6-\mathrm{Me}_{2} \mathrm{C}_{6} \mathrm{H}_{3} \mathrm{OH}<2,6-\mathrm{Cl}_{2} \mathrm{C}_{6} \mathrm{H}_{3} \mathrm{OH}<2,6-\mathrm{F}_{2} \mathrm{C}_{6} \mathrm{H}_{3} \mathrm{OH}$, irrespective of the kind of the arylimido ligands employed. The order is also somewhat different from that of $\mathrm{p} K_{\mathrm{a}}$ values (employed for estimation of the electronic nature), and the reactions of $\mathrm{V}\left(\mathrm{NAr}^{\prime}\right)\left(\mathrm{CH}_{2} \mathrm{SiMe}_{3}\right)_{3}$ with 1.0 (and 3.0) equiv of $2,6-{ }^{t} \mathrm{Bu}_{2} \mathrm{C}_{6} \mathrm{H}_{3} \mathrm{OH}$ did not take place even upon heating at 60 ${ }^{\circ} \mathrm{C} .{ }^{56}$ Taking into account these results, it is highly suggested that, as proposed previously, ${ }^{42,48-50}$ the reactions proceeded by coordination of phenols into the vanadium metal center. Through this study, it is clear that steric bulk in both arylimido and phenol affects the substitution rate. We highly believe that the results should be promising and should be useful for better understanding, especially in the field of organometallic chemistry of vanadium.

\section{EXPERIMENTAL SECTION}

General Procedures. All experiments were performed under a nitrogen atmosphere in a vacuum atmosphere (VAC) drybox. Anhydrous grade $n$-hexane, tetrahydrofuran, and dichloromethane (Kanto Chemical Co., Inc.) and n-octane (Aldrich) were stored in a bottle containing molecular sieves (a mixture of $3 \mathrm{~A} 1 / 16,4 \mathrm{~A} 1 / 8$, and $13 \mathrm{X} 1 / 16$ ) in the drybox and were passed through a short alumina column under a $\mathrm{N}_{2}$ stream prior to use. The other reagents (phenols) of reagent grade were dried in the presence of molecular sieves and alumina passed through a short column prior to use. $\mathrm{V}(\mathrm{NPh}) \mathrm{Cl}_{3},{ }^{61} \mathrm{~V}(\mathrm{~N}-2$ $\left.\mathrm{MeC}_{6} \mathrm{H}_{4}\right) \mathrm{Cl}_{3},{ }^{62} \mathrm{~V}\left(\mathrm{~N}-2,6-\mathrm{Me}_{2} \mathrm{C}_{6} \mathrm{H}_{3}\right) \mathrm{Cl}_{3},{ }^{63} \mathrm{~V}(\mathrm{NPh})-$ $\left(\mathrm{CH}_{2} \mathrm{SiMe}_{3}\right)_{3},{ }^{54} \mathrm{~V}\left(\mathrm{~N}-2,6-\mathrm{Me}_{2} \mathrm{C}_{6} \mathrm{H}_{3}\right)\left(\mathrm{CH}_{2} \mathrm{SiMe}_{3}\right)_{3}{ }^{48} \mathrm{~V}(\mathrm{~N}-2,6-$ $\left.\mathrm{Me}_{2} \mathrm{C}_{6} \mathrm{H}_{3}\right)\left(\mathrm{CH}_{2} \mathrm{SiMe}_{3}\right)_{2}\left(\mathrm{O}-2,6-\mathrm{F}_{2} \mathrm{C}_{6} \mathrm{H}_{3}\right)$ (3a), ${ }^{49} \mathrm{~V}(\mathrm{~N}-2,6-$ $\left.\mathrm{Me}_{2} \mathrm{C}_{6} \mathrm{H}_{3}\right)\left(\mathrm{CH}_{2} \mathrm{SiMe}_{3}\right)_{2}\left(\mathrm{O}-2,6-\mathrm{Me}_{2} \mathrm{C}_{6} \mathrm{H}_{3}\right)$ (3c), ${ }^{48} \mathrm{~V}(\mathrm{~N}-2,6-$ $\left.\mathrm{Me}_{2} \mathrm{C}_{6} \mathrm{H}_{3}\right)\left(\mathrm{CH}_{2} \mathrm{SiMe}_{3}\right)_{2}\left(\mathrm{O}-2,6-{ }_{-}{ }^{-} \mathrm{Pr}_{2} \mathrm{C}_{6} \mathrm{H}_{3}\right)(3 \mathrm{~d}){ }^{48}$ and $\mathrm{V}(\mathrm{N}$ 2,6- $\left.\mathrm{Me}_{2} \mathrm{C}_{6} \mathrm{H}_{3}\right)\left(\mathrm{CH}_{2} \mathrm{SiMe}_{3}\right)_{2}\left(\mathrm{OC}_{6} \mathrm{H}_{5}\right)^{48}$ were prepared according to the previous reports.

All NMR spectra were recorded on a Bruker AV500 spectrometer $\left(500.13 \mathrm{MHz}\right.$ for ${ }^{1} \mathrm{H}, 125.77 \mathrm{MHz}$ for ${ }^{13} \mathrm{C}$, 470.59 MHz for ${ }^{19} \mathrm{~F}, 202.47 \mathrm{MHz}$ for ${ }^{31} \mathrm{P}, 131.55 \mathrm{MHz}$ for ${ }^{51} \mathrm{~V}$ ) unless otherwise noted. All spectra were obtained at $25{ }^{\circ} \mathrm{C}$ unless otherwise noted. Chemical shifts are given in $\mathrm{ppm}$ and are referenced to $\mathrm{SiMe}_{4}\left(\delta 0.00,{ }^{1} \mathrm{H},{ }^{13} \mathrm{C}\right), \mathrm{CFCl}_{3}\left(\delta 0.00,{ }^{19} \mathrm{~F}\right)$ and $\mathrm{VOCl}_{3}\left(\delta 0.00,{ }^{51} \mathrm{~V}\right)$. Coupling constants and half-width values, $\Delta \nu_{1 / 2}$, are given in hertz. Elemental analyses were performed by 
using an EAI CE-440 CHN/O/S Elemental Analyzer (Exeter Analytical, Inc.)

Synthesis of $\mathrm{V}(\mathrm{NPh})\left(\mathrm{CH}_{2} \mathrm{SiMe}_{3}\right)_{2}\left(\mathrm{O}-2,6-\mathrm{F}_{2} \mathrm{C}_{6} \mathrm{H}_{3}\right)(\mathrm{Ia})$. Into an $n$-hexane solution $(30 \mathrm{~mL})$ containing $\mathrm{V}(\mathrm{NPh})\left(\mathrm{CH}_{2} \mathrm{SiMe}_{3}\right)_{3}$ (407 mg, $1.01 \mathrm{mmol}$ ) was added 2,6- $\mathrm{F}_{2} \mathrm{C}_{6} \mathrm{H}_{3} \mathrm{OH}$ (156 mg, 1.20 $\mathrm{mmol})$ at $-30{ }^{\circ} \mathrm{C}$. The solution was stirred at room temperature for $5 \mathrm{~h}$, and the completion of consumption of 2,6- $\mathrm{F}_{2} \mathrm{C}_{6} \mathrm{H}_{3} \mathrm{OH}$ was confirmed by ${ }^{1} \mathrm{H}$ NMR spectrum. The resultant solution was filtered through a celite pad; the filter cake was washed with $n$-hexane. The filtrate and the wash liquid were placed into a rotary evaporator combined to remove volatiles, affording a sticky brown liquid. Yield: $237 \mathrm{mg}(87 \%) .{ }^{1} \mathrm{H}$ NMR $\left(\mathrm{C}_{6} \mathrm{D}_{6}\right): \delta$ 0.13 (s, 18H, CH $\mathrm{CiMe}_{3}$ ), 2.37 (s, 2H, $\left.\mathrm{CH}_{2} \mathrm{SiMe}_{3}\right), 2.91$ (br, $2 \mathrm{H}$, $\mathrm{CH}_{2} \mathrm{SiMe}_{3}$ ), 6.21 (br, $\left.1 \mathrm{H}, \mathrm{Ar}-\mathrm{H}\right), 6.51$ (br, $\left.2 \mathrm{H}, \mathrm{Ar}-\mathrm{H}\right), 6.80(\mathrm{t}$, $1 \mathrm{H}, J=7.4, \operatorname{Ar}-H), 7.02(\mathrm{t}, 2 \mathrm{H}, J=7.5, \operatorname{Ar}-H), 7.51$ (d, $2 \mathrm{H}, J=$ 7.8, $\mathrm{Ar}-H) .{ }^{51} \mathrm{~V}$ NMR $\left(\mathrm{C}_{6} \mathrm{D}_{6}\right): \delta 577\left(\Delta \nu_{1 / 2}=314 \mathrm{~Hz}\right) \cdot{ }^{19} \mathrm{~F}$ $\operatorname{NMR}\left(\mathrm{C}_{6} \mathrm{D}_{6}\right): \delta-129.0(\mathrm{~s}) .{ }^{13} \mathrm{C} \mathrm{NMR}\left(\mathrm{C}_{6} \mathrm{D}_{6}\right): \delta 1.7\left(\mathrm{SiMe}_{3}\right)$, 90.3-94.4 (br, $\mathrm{V}-\mathrm{CH}_{2}$ ), 111.6, 120.3, 125.5, 126.2, 128.7, 153.0, 154.9, 166.0 (Ar). Anal. calcd for $\mathrm{C}_{20} \mathrm{H}_{30} \mathrm{~F}_{2} \mathrm{NOSi}_{2} \mathrm{~V}$ : C, 53.91; H, 6.79; N, 3.14. Found: C, 53.86; H, 6.75; N, 3.13.

Synthesis of $\mathrm{V}(\mathrm{NPh})\left(\mathrm{CH}_{2} \mathrm{SiMe}_{3}\right)_{2}\left(\mathrm{O}-2,6-\mathrm{Cl}_{2} \mathrm{C}_{6} \mathrm{H}_{3}\right)(1 \mathrm{~b})$. Synthesis of $\mathbf{1 b}$ was carried out by the same procedure as that for $1 \mathbf{a}$ except that $\mathrm{V}(\mathrm{NPh})\left(\mathrm{CH}_{2} \mathrm{SiMe}_{3}\right)_{3}(288 \mathrm{mg}, 0.713 \mathrm{mmol})$ was used and 2,6- $\mathrm{Cl}_{2} \mathrm{C}_{6} \mathrm{H}_{3} \mathrm{OH}(116 \mathrm{mg}, 0.712 \mathrm{mmol})$ was added in the place of 2,6- $\mathrm{F}_{2} \mathrm{C}_{6} \mathrm{H}_{3} \mathrm{OH}$. Yield: $336 \mathrm{mg}$ (99\%). ${ }^{1} \mathrm{H}$ NMR $\left(\mathrm{C}_{6} \mathrm{D}_{6}\right): \delta 0.15\left(\mathrm{~s}, 18 \mathrm{H}, \mathrm{CH}_{2} \mathrm{SiMe}_{3}\right), 2.34\left(\mathrm{br}, 2 \mathrm{H}, \mathrm{CH}_{2} \mathrm{SiMe}_{3}\right)$, $3.15\left(\mathrm{br}, 2 \mathrm{H}, \mathrm{CH}_{2} \mathrm{SiMe}_{3}\right), 6.20(\mathrm{t}, 1 \mathrm{H}, \mathrm{J}=8.0, \mathrm{Ar}-\mathrm{H}), 6.81(\mathrm{t}, 1 \mathrm{H}$, $J=7.3$, Ar- $H$ ), 6.93 (d, 2H, $J=8.1, \operatorname{Ar}-H), 7.03(\mathrm{t}, 2 \mathrm{H}, J=7.6, \mathrm{Ar}-$ $H), 7.52(\mathrm{~d}, 2 \mathrm{H}, J=7.8, \mathrm{Ar}-H) .{ }^{51} \mathrm{~V}$ NMR $\left(\mathrm{C}_{6} \mathrm{D}_{6}\right): \delta 500\left(\Delta \nu_{1 / 2}\right.$ $=309 \mathrm{~Hz}) .{ }^{13} \mathrm{C} \mathrm{NMR}\left(\mathrm{C}_{6} \mathrm{D}_{6}\right): \delta 1.87\left(\mathrm{SiMe}_{3}\right), 95.0\left(\mathrm{br}, \mathrm{V}-\mathrm{CH}_{2}\right)$, $118.6,120.9,121.8,125.1,125.5,125.8,126.2,156.6,165.3$ (Ar). Anal. calcd for $\mathrm{C}_{20} \mathrm{H}_{30} \mathrm{Cl}_{2} \mathrm{NOSiV}$ : C, 50.20, $\mathrm{H}, 6.32, \mathrm{~N}$, 2.93. Found: $49.69, \mathrm{H}, 6.13, \mathrm{~N}, 3.02$. The observed $\mathrm{C}$ values was somewhat low, probably due to incomplete combustion (by production of vanadium carbide), whereas both $\mathrm{H}$ and $\mathrm{N}$ observed value were close to the calculated values.

Synthesis of V(NPh) $\left(\mathrm{CH}_{2} \mathrm{SiMe}_{3}\right)_{2}\left(\mathrm{O}-2,6-\mathrm{Me}_{2} \mathrm{C}_{6} \mathrm{H}_{3}\right)$ (1c). Synthesis of $1 \mathrm{c}$ was carried out by the same procedure as that for $1 \mathrm{a}$ except that $\mathrm{V}(\mathrm{NPh})\left(\mathrm{CH}_{2} \mathrm{SiMe}_{3}\right)_{3}(400 \mathrm{mg}, 0.991 \mathrm{mmol})$ was used and 2,6- $\mathrm{Me}_{2} \mathrm{C}_{6} \mathrm{H}_{3} \mathrm{OH}(122 \mathrm{mg}, 1.00 \mathrm{mmol})$ was added in the place of 2,6- $\mathrm{F}_{2} \mathrm{C}_{6} \mathrm{H}_{3} \mathrm{OH}$. Yield: $258 \mathrm{mg}$ (99\%). ${ }^{1} \mathrm{H}$ NMR $\left(\mathrm{C}_{6} \mathrm{D}_{6}\right): \delta 0.14\left(\mathrm{~s}, 18 \mathrm{H}, \mathrm{CH}_{2} \mathrm{SiMe}_{3}\right), 2.15\left(\mathrm{br}, 2 \mathrm{H}, \mathrm{CH}_{2} \mathrm{SiMe}_{3}\right)$, 2.34 (s, 6H, Ar-Me), 2.66 (br, 2H, $\mathrm{CH}_{2} \mathrm{SiMe}_{3}$ ), 6.78 (m, 2H, Ar$H$ ), 6.93 (d, 2H, J = 7.4, Ar-H), 7.01 (t, 2H, $J=7.6, \mathrm{Ar}-H), 7.37$

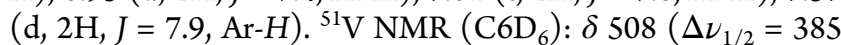
$\mathrm{Hz}) .{ }^{13} \mathrm{C}$ NMR $\left(\mathrm{C}_{6} \mathrm{D}_{6}\right): \delta 2.03(\mathrm{SiMe}), 17.7\left(2,6-\mathrm{Me}_{2} \mathrm{C}_{6} \mathrm{H}_{3}\right)$, 85.5-90.9 (br, V-CH $\left.{ }_{2}\right), 120.2,122.5,122.6,125.4,125.8,126.2$, 127.0, 128.7, 128.8, 129.1, 164.8 (Ar). Anal. calcd for $\mathrm{C}_{22} \mathrm{H}_{36} \mathrm{NOSi}_{2} \mathrm{~V}$ : C, 60.38; H, 8.29; N, 3.20. Found: C, 60.28; $\mathrm{H}, 8.10 ; \mathrm{N}, 3.29$.

Synthesis of $\mathrm{V}(\mathrm{NPh})\left(\mathrm{CH}_{2} \mathrm{SiMe}_{3}\right)_{2}\left(\mathrm{O}-2,6-{ }^{i} \mathrm{Pr}_{2} \mathrm{C}_{6} \mathrm{H}_{3}\right)$ (1d). Synthesis of $\mathbf{1 d}$ was carried out by the same procedure as that for $1 \mathrm{a}$ except that $\mathrm{V}(\mathrm{NPh})\left(\mathrm{CH}_{2} \mathrm{SiMe}_{3}\right)_{3}(412 \mathrm{mg}, 1.02 \mathrm{mmol})$ was used and 2,6- ${ }_{-}^{i} \mathrm{Pr}_{2} \mathrm{C}_{6} \mathrm{H}_{3} \mathrm{OH}$ (179 mg, $1.01 \mathrm{mmol}$ ) was added in the place of 2,6- $\mathrm{F}_{2} \mathrm{C}_{6} \mathrm{H}_{3} \mathrm{OH}$. Yield: $487 \mathrm{mg}(98 \%) .{ }^{1} \mathrm{H}$ NMR $\left(\mathrm{C}_{6} \mathrm{D}_{6}\right): \delta 0.16\left(\mathrm{~s}, 18 \mathrm{H}, \mathrm{CH}_{2} \mathrm{SiMe}_{3}\right), 1.26\left(\mathrm{~d}, 12 \mathrm{H}, J=6.9,{ }^{i} \mathrm{Pr}\right)$, $2.10\left(\mathrm{~d}, 2 \mathrm{H}, J=9.4, \mathrm{CH}_{2} \mathrm{SiMe}_{3}\right), 2.86(\mathrm{~d}, 2 \mathrm{H}, J=9.6$, $\mathrm{CH}_{2} \mathrm{SiMe}_{3}$ ), 3.73 (sep, $\left.2 \mathrm{H}, J=6.9,{ }^{i} \mathrm{Pr}\right), 6.79$ (t, $1 \mathrm{H}, J=7.43$, Ar$H), 6.96(\mathrm{t}, 1 \mathrm{H}, J=7.6, \mathrm{Ar}-\mathrm{H}), 7.02(\mathrm{t}, 2 \mathrm{H}, J=7.9, \mathrm{Ar}-H), 7.06$ (d, $2 \mathrm{H}, J=7.6, \mathrm{Ar}-\mathrm{H}), 7.42(\mathrm{~d}, 2 \mathrm{H}, J=7.7, \mathrm{Ar}-\mathrm{H}) .{ }^{51} \mathrm{~V}$ NMR $\left(\mathrm{C}_{6} \mathrm{D}_{6}\right): \delta 500\left(\Delta \nu_{1 / 2}=323 \mathrm{~Hz}\right) .{ }^{13} \mathrm{C} \operatorname{NMR}\left(\mathrm{C}_{6} \mathrm{D}_{6}\right): \delta 2.1$ $\left.(\mathrm{SiMe})_{3}\right), 23.6\left(\mathrm{Me}_{2} \mathrm{CH}-\right), 27.1\left(\mathrm{Me}_{2} \mathrm{CH}-\right), 88.2\left(\mathrm{br}, \mathrm{V}-\mathrm{CH}_{2}\right)$, 120.2 , 123.3, 123.4, 125.3, 125.7, 126.3, 128.7, 128.9, 137.7,
137.9, 160.7, 164.2 (Ar). Anal. calcd for $\mathrm{C}_{26} \mathrm{H}_{44} \mathrm{NOSi}_{2} \mathrm{~V}: \mathrm{C}$, 63.25; H, 8.98; N, 2.84. Found: C, 62.97; H, 9.16; N, 2.96.

Synthesis of $\mathrm{V}(\mathrm{NPh})\left(\mathrm{CH}_{2} \mathrm{SiMe}_{3}\right)_{2}\left(\mathrm{O}-2-{ }^{t} \mathrm{BuC}{ }_{6} \mathrm{H}_{4}\right)$ (1e). Synthesis of 1e was carried out by the same procedure as that for 1a except that $\mathrm{V}(\mathrm{NPh})\left(\mathrm{CH}_{2} \mathrm{SiMe}_{3}\right)_{3}(402 \mathrm{mg}, 0.996 \mathrm{mmol})$ was used and $2-{ }^{t} \mathrm{BuC}_{6} \mathrm{H}_{4} \mathrm{OH}(150 \mathrm{mg}, 1.00 \mathrm{mmol})$ was added in the place of 2,6- $\mathrm{F}_{2} \mathrm{C}_{6} \mathrm{H}_{3} \mathrm{OH}$. Yield: $461 \mathrm{mg}(99 \%) .{ }^{1} \mathrm{H}$ NMR $\left(\mathrm{C}_{6} \mathrm{D}_{6}\right)$ : $\delta 0.11\left(\mathrm{~s}, 18 \mathrm{H}, \mathrm{CH}_{2} \mathrm{SiMe}_{3}\right.$ ), $1.70\left(\mathrm{~s}, 9 \mathrm{H},{ }^{t} \mathrm{Bu}\right), 2.07$ (br, $2 \mathrm{H}$, $\mathrm{CH}_{2} \mathrm{SiMe}_{3}$ ), 2.79 (br, $\left.2 \mathrm{H}, \mathrm{CH}_{2} \mathrm{SiMe}_{3}\right), 6.82(\mathrm{~m}, 2 \mathrm{H}, \mathrm{Ar}-\mathrm{H}), 6.91$ $\left(\mathrm{dt}, 1 \mathrm{H},{ }^{3} \mathrm{~J}_{\mathrm{H}-\mathrm{H}}=8.0,{ }^{4} \mathrm{~J}_{\mathrm{H}-\mathrm{H}}=1.4, \mathrm{Ar}-\mathrm{H}\right), 7.05(\mathrm{t}, 2 \mathrm{H}, J=7.8, \mathrm{Ar}-$ $H), 7.21\left(\mathrm{~d}, 1 \mathrm{H},{ }^{3} \mathrm{~J}_{\mathrm{H}-\mathrm{H}}=8.0, \operatorname{Ar}-\mathrm{H}\right), 7.25\left(\mathrm{dd}, 1 \mathrm{H},{ }^{3} \mathrm{~J}_{\mathrm{H}-\mathrm{H}}=7.8\right.$, $\left.{ }^{4} J_{\mathrm{H}-\mathrm{H}}=1.4, \mathrm{Ar}-\mathrm{H}\right), 7.55(\mathrm{~d}, 2 \mathrm{H}, \mathrm{J}=7.7, \mathrm{Ar}-\mathrm{H}) .{ }^{51} \mathrm{~V}$ NMR $\left(\mathrm{C}_{6} \mathrm{D}_{6}\right): \delta 500\left(\Delta \nu_{1 / 2}=312 \mathrm{~Hz}\right) \cdot{ }^{13} \mathrm{C} \mathrm{NMR}\left(\mathrm{C}_{6} \mathrm{D}_{6}\right): \delta 2.2$ $\left(\mathrm{SiMe}_{3}\right), 30.5\left(\mathrm{Me}_{3} \mathrm{C}-\right)$, $35.2\left(\mathrm{Me}_{3} \mathrm{C}-\right), 86.2-89.8\left(\mathrm{br}, \mathrm{V}-\mathrm{CH}_{2}\right)$, $119.8,123.3,125.5,125.9,126.8,127.6,128.9,129.3,135.5$, 162.9 (Ar). Anal. calcd for $\mathrm{C}_{24} \mathrm{H}_{40} \mathrm{NOSi}_{2} \mathrm{~V}: \mathrm{C}, 61.90 ; \mathrm{H}, 8.66 ; \mathrm{N}$, 3.01. Found: C, 62.15; H, 8.83; N, 2.97.

Synthesis of $\mathrm{V}\left(\mathrm{N}-2-\mathrm{MeC}_{6} \mathrm{H}_{4}\right)\left(\mathrm{CH}_{2} \mathrm{SiMe}_{3}\right)_{3}$. Into an tetrahydrofuran solution $(60 \mathrm{~mL})$ containing $\mathrm{LiCH}_{2} \mathrm{SiMe}_{3}(1.96 \mathrm{~g}, 20.8$ $\mathrm{mmol})$ was added $\mathrm{V}\left(\mathrm{N}-2-\mathrm{MeC}_{6} \mathrm{H}_{4}\right) \mathrm{Cl}_{3}(1.78 \mathrm{~g}, 6.78 \mathrm{mmol})$ at $-30{ }^{\circ} \mathrm{C}$. The solution was stirred at room temperature for $3 \mathrm{~h}$. The resultant solution was filtered through a Celite Pad, the filter cake was washed with $n$-hexane. Combined, the filtrate and the wash liquid were placed into a rotary evaporator to remove volatiles, affording a sticky brown liquid. Yield: $1.84 \mathrm{~g}(65 \%) .{ }^{1} \mathrm{H}$ NMR $\left(\mathrm{C}_{6} \mathrm{D}_{6}\right): \delta 0.13\left(\mathrm{~s}, 24 \mathrm{H}, \mathrm{CH}_{2} \mathrm{SiMe}_{3}\right), 1.88(\mathrm{br}, 6 \mathrm{H}$, $\mathrm{CH}_{2} \mathrm{SiMe}_{3}$ ), 2.71 (s, 3H, Ar-Me), $6.84(\mathrm{t}, 1 \mathrm{H}, J=7.4, \mathrm{Ar}-\mathrm{H})$, 7.05 (m, 2H, Ar-H), 7.72 (d, 1H, $J=7.8$, Ar-H). ${ }^{51} \mathrm{~V}$ NMR $\left(\mathrm{C}_{6} \mathrm{D}_{6}\right): \delta$ 1059. ${ }^{13} \mathrm{C}$ NMR $\left(\mathrm{C}_{6} \mathrm{D}_{6}\right): \delta 2.2\left(\mathrm{SiMe}_{3}\right), 19.7(2-$ $\mathrm{MeC}_{6} \mathrm{H}_{4}$ ), 87.1-90.6 (br, V-CH $\mathrm{CH}_{2}$, 125.4, 126.3, 126.6, 130.5, 133.3164 .8 (Ar). Several attempts for analysis failed due to its appearing very sensitive (probably toward impurities, including even a trace amount of moisture and oxygen).

Synthesis of $\mathrm{V}\left(\mathrm{N}-2-\mathrm{MeC}_{6} \mathrm{H}_{4}\right)\left(\mathrm{CH}_{2} \mathrm{SiMe}_{3}\right)_{2}\left(\mathrm{O}-2,6-\mathrm{F}_{2} \mathrm{C}_{6} \mathrm{H}_{3}\right)$ (2a). Into an $n$-hexane solution $(30 \mathrm{~mL})$ containing $\mathrm{V}(\mathrm{N}-2$ $\left.\mathrm{MeC}_{6} \mathrm{H}_{4}\right)\left(\mathrm{CH}_{2} \mathrm{SiMe}_{3}\right)_{3}(202 \mathrm{mg}, 0.484 \mathrm{mmol})$ was added 2,6$\mathrm{F}_{2} \mathrm{C}_{6} \mathrm{H}_{3} \mathrm{OH}(70 \mathrm{mg}, 0.538 \mathrm{mmol})$ at $-30{ }^{\circ} \mathrm{C}$. The solution was stirred at room temperature for $5 \mathrm{~h}$, and completion of consumption of $2,6-\mathrm{F}_{2} \mathrm{C}_{6} \mathrm{H}_{3} \mathrm{OH}$ was confirmed by ${ }^{1} \mathrm{H}$ NMR spectrum. The resultant solution was filtered through a celite pad and the filter cake was washed with $n$-hexane. Combined, the filtrate and the wash liquid were placed into a rotary evaporator to remove volatiles, affording a sticky brown liquid. Yield: $194 \mathrm{mg}(87 \%) .{ }^{1} \mathrm{H}$ NMR $\left(\mathrm{C}_{6} \mathrm{D}_{6}\right): \delta 0.14(\mathrm{~s}, 18 \mathrm{H}$, $\mathrm{CH}_{2} \mathrm{SiMe}_{3}$ ), 2.44 (br, 2H, $\mathrm{CH}_{2} \mathrm{SiMe}_{3}$ ), 2.54 (s, 3H, Ar-Me), 2.86 (br, $\left.2 \mathrm{H}, \mathrm{CH}_{2} \mathrm{SiMe}_{3}\right), 6.23(\mathrm{~m}, 1 \mathrm{H}, \mathrm{Ar}-\mathrm{H}), 6.52(\mathrm{t}, 2 \mathrm{H}, J=7.7$, $\operatorname{Ar}-H), 6.76(\mathrm{t}, 1 \mathrm{H}, J=7.4$, Ar- $H), 6.93(\mathrm{~m}, 2 \mathrm{H}, \mathrm{Ar}-\mathrm{H}), 7.57$ (d, $1 \mathrm{H}, J=7.8, \mathrm{Ar}-H) .{ }^{51} \mathrm{~V}$ NMR $\left(\mathrm{C}_{6} \mathrm{D}_{6}\right): \delta 595\left(\Delta \nu_{1 / 2}=320 \mathrm{~Hz}\right)$. ${ }^{19} \mathrm{~F}$ NMR $\left(\mathrm{C}_{6} \mathrm{D}_{6}\right): \delta-128.7\left(\mathrm{t},{ }^{4} J_{\mathrm{F}-\mathrm{F}}=6.6\right) .{ }^{13} \mathrm{C}$ NMR $\left(\mathrm{C}_{6} \mathrm{D}_{6}\right): \delta$ $1.6\left(\mathrm{SiMe}_{3}\right), 18.8\left(2-\mathrm{MeC}_{6} \mathrm{H}_{4}\right), 95.6\left(\mathrm{br}, \mathrm{V}-\mathrm{CH}_{2}\right), 111.4(\mathrm{dd}$, $\left.{ }^{2} J_{\mathrm{C}-\mathrm{F}}=16.4,{ }^{4} J_{\mathrm{C}-\mathrm{F}}=5.9\right), 120.0\left(\mathrm{t},{ }^{3} J_{\mathrm{C}-\mathrm{F}}=8.8\right), 126.3,126.3$, $127.1,130.2,134.3(\mathrm{Ar}), 153.7\left(\mathrm{dd},{ }^{1} J_{\mathrm{C}-\mathrm{F}}=247,{ }^{3} J_{\mathrm{C}-\mathrm{F}}=4.7\right)$, 161.0 (Ar). Anal. calcd for $\mathrm{C}_{21} \mathrm{H}_{32} \mathrm{~F}_{2} \mathrm{NOSi}_{2} \mathrm{~V}: \mathrm{C}, 54.88 ; \mathrm{H}, 7.02$; $\mathrm{N}, 3.05$. Found(1): C, 54.21; H, 6.76; N, 3.12. Found(2): C, $54.52 ; \mathrm{H}, 6.83 ; \mathrm{N}, 3.34$. The observed $\mathrm{C}$ values were somewhat low because of the incomplete combustion (by production of vanadium carbide), whereas both $\mathrm{H}$ and $\mathrm{N}$ observed values were close to the calculated values.

Synthesis of $\mathrm{V}\left(\mathrm{N}-2-\mathrm{MeC}_{6} \mathrm{H}_{4}\right)\left(\mathrm{CH}_{2} \mathrm{SiMe}_{3}\right)_{2}\left(\mathrm{O}-2,6-\mathrm{Cl}_{2} \mathrm{C}_{6} \mathrm{H}_{3}\right)$ (2b). Synthesis of $\mathbf{2 b}$ was carried out by the same procedure as that for $2 \mathrm{a}$ except that $\mathrm{V}\left(\mathrm{N}-2-\mathrm{MeC}_{6} \mathrm{H}_{4}\right)\left(\mathrm{CH}_{2} \mathrm{SiMe}_{3}\right)_{3}(217$ $\mathrm{mg}, 0.519 \mathrm{mmol}$ ) was used and 2,6- $\mathrm{Cl}_{2} \mathrm{C}_{6} \mathrm{H}_{3} \mathrm{OH}$ (108 mg, 0.662 
mmol) was added in the place of $2,6-\mathrm{F}_{2} \mathrm{C}_{6} \mathrm{H}_{3} \mathrm{OH}$. Yield: $233 \mathrm{mg}$ (91\%). ${ }^{1} \mathrm{H}$ NMR $\left(\mathrm{C}_{6} \mathrm{D}_{6}\right): \delta 0.14\left(\mathrm{~s}, 18 \mathrm{H}, \mathrm{CH}_{2} \mathrm{SiMe}_{3}\right), 2.45$ (d, $2 \mathrm{H}, \mathrm{J}=7.6, \mathrm{CH}_{2} \mathrm{SiMe}_{3}$ ) 2.56 (s, 3H, Ar- $\mathrm{Me}$ ), 2.99 (d, 2H, J = 7.2, $\left.\mathrm{CH}_{2} \mathrm{SiMe}_{3}\right), 6.20(\mathrm{t}, 1 \mathrm{H}, J=8.0, \mathrm{Ar}-\mathrm{H}), 6.77(\mathrm{~m}, 1 \mathrm{H}, \mathrm{Ar}-\mathrm{H}), 6.93$ $(\mathrm{m}, 4 \mathrm{H}, \mathrm{Ar}-\mathrm{H}), 7.57(\mathrm{~d}, 1 \mathrm{H}, J=7.8, \mathrm{Ar}-H) .{ }^{51} \mathrm{~V} \mathrm{NMR}\left(\mathrm{C}_{6} \mathrm{D}_{6}\right): \delta$ $619\left(\Delta \nu_{1 / 2}=325 \mathrm{~Hz}\right) .{ }^{13} \mathrm{C} \mathrm{NMR}\left(\mathrm{C}_{6} \mathrm{D}_{6}\right): \delta 1.8\left(\mathrm{SiMe}_{3}\right), 18.9(2-$ $\mathrm{MeC}_{6} \mathrm{H}_{4}$ ), 91.1-95.5 (br, V-CH$), 121.9,125.6,126.3$, 126.3, 127.5, 128.4, 130.3, 134.4, 157.1, 159.3 (Ar). Anal. calcd for $\mathrm{C}_{21} \mathrm{H}_{32} \mathrm{Cl}_{2} \mathrm{NOSi}_{2} \mathrm{~V}$ : C, 51.21; H, 6.55; N, 2.84. Found: C, 50.97; $\mathrm{H}, 6.66$; N, 2.73 .

Synthesis of $\mathrm{V}\left(\mathrm{N}-2-\mathrm{MeC}_{6} \mathrm{H}_{4}\right)\left(\mathrm{CH}_{2} \mathrm{SiMe}_{3}\right)_{2}\left(\mathrm{O}-2,6-\mathrm{Me}_{2} \mathrm{C}_{6} \mathrm{H}_{3}\right)$ (2c). Synthesis of $2 \mathrm{c}$ was carried out by the same procedure as that for 2a except that $\mathrm{V}\left(\mathrm{N}-2-\mathrm{MeC}_{6} \mathrm{H}_{4}\right)\left(\mathrm{CH}_{2} \mathrm{SiMe}_{3}\right)_{3}(302 \mathrm{mg}$, $0.723 \mathrm{mmol}$ ) was used and $2,6-\mathrm{Me}_{2} \mathrm{C}_{6} \mathrm{H}_{3} \mathrm{OH}(88 \mathrm{mg}, 0.720$ mmol) was added in the place of 2,6- $\mathrm{F}_{2} \mathrm{C}_{6} \mathrm{H}_{3} \mathrm{OH}$. Yield: $310 \mathrm{mg}$ (95\%). ${ }^{1} \mathrm{H}$ NMR $\left(\mathrm{C}_{6} \mathrm{D}_{6}\right): \delta 0.16\left(\mathrm{~s}, 18 \mathrm{H}, \mathrm{CH}_{2} \mathrm{SiMe}_{3}\right), 2.29(\mathrm{~m}$, $8 \mathrm{H}, \mathrm{Ar}-\mathrm{Me}$ and $\left.\mathrm{CH}_{2} \mathrm{SiMe}_{3}\right) 2.40$ (d, 2H, J = 7.2, $\mathrm{CH}_{2} \mathrm{SiMe}_{3}$ ), 2.47 (s, 3H, Ar- $\mathrm{Me}$ ), 6.76-6.79 (m, 2H, Ar-H), 6.89-6.93 (m, $4 \mathrm{H}, \mathrm{Ar}-H), 7.38(\mathrm{~d}, 1 \mathrm{H}, J=7.6, \mathrm{Ar}-H) .{ }^{51} \mathrm{~V} \mathrm{NMR}\left(\mathrm{C}_{6} \mathrm{D}_{6}\right): \delta 512$ $\left(\Delta \nu_{1 / 2}=352 \mathrm{~Hz}\right) .{ }^{13} \mathrm{C} \mathrm{NMR}\left(\mathrm{C}_{6} \mathrm{D}_{6}\right): \delta 2.0\left(\mathrm{SiMe}_{3}\right), 19.1$ $\left.\mathrm{MeC}_{6} \mathrm{H}_{4}\right), 30.4\left(\mathrm{Me}_{2} \mathrm{CH}-\right), 35.2\left(\mathrm{Me}_{2} \mathrm{CH}-\right), 123.3,123.4$, 126.0, 126.4, 126.7, 126.5, 127.5, 130.5, 134.2, 135.6, 152.8 (Ar). Anal. calcd for $\mathrm{C}_{23} \mathrm{H}_{38} \mathrm{NOVSi}_{2} \mathrm{~V}: \mathrm{C}, 61.16, \mathrm{H}, 8.48, \mathrm{~N}$, 3.10. Found(1): C, 60.57, H, 8.33, N, 3.44. Found(2): C, 60.5, $\mathrm{H}, 8.05, \mathrm{~N}, 3.4$. The observed $C$ values were somewhat low because of the incomplete combustion (by production of vanadium carbide), whereas both $\mathrm{H}$ and $\mathrm{N}$ observed values were close to the calculated values.

Synthesis of $\mathrm{V}\left(\mathrm{N}-2-\mathrm{MeC}_{6} \mathrm{H}_{4}\right)\left(\mathrm{CH}_{2} \mathrm{SiMe}_{3}\right)_{2}\left(\mathrm{O}-2,6-{ }^{i} \mathrm{Pr}_{2} \mathrm{C}_{6} \mathrm{H}_{3}\right)$ (2d). Synthesis of $\mathbf{2 d}$ was carried out by the same procedure as that for $2 \mathrm{a}$ except that $\mathrm{V}\left(\mathrm{N}-2-\mathrm{MeC}_{6} \mathrm{H}_{4}\right)\left(\mathrm{CH}_{2} \mathrm{SiMe}_{3}\right)_{3}(303$ $\mathrm{mg}, 0.725 \mathrm{mmol}$ ) was used and 2,6- ${ }^{i} \mathrm{Pr}_{2} \mathrm{C}_{6} \mathrm{H}_{3} \mathrm{OH}(130 \mathrm{mg}, 0.729$ $\mathrm{mmol}$ ) was added in the place of $2,6-\mathrm{F}_{2} \mathrm{C}_{6} \mathrm{H}_{3} \mathrm{OH}$ and the reaction mixture was stirred overnight. Yield: $359 \mathrm{mg}(98 \%) .{ }^{1} \mathrm{H}$ $\operatorname{NMR}\left(\mathrm{C}_{6} \mathrm{D}_{6}\right): \delta 0.18\left(\mathrm{~s}, 18 \mathrm{H}, \mathrm{CH}_{2} \mathrm{SiMe}_{3}\right), 1.23(\mathrm{~d}, 12 \mathrm{H}, J=6.9$, $\left.{ }^{i} \mathrm{Pr}\right) 2.19$ (d, $2 \mathrm{H}, \mathrm{J}=10.5, \mathrm{CH}_{2} \mathrm{SiMe}_{3}$ ), 2.45 (s, 3H, Ar-Me), 2.56 (d, $2 \mathrm{H}, J=10.5, \mathrm{CH}_{2} \mathrm{SiMe}_{3}$ ), 3.61 (sep, $\left.2 \mathrm{H}, J=6.9,{ }^{i} \mathrm{Pr}\right), 6.74(\mathrm{t}$, $1 \mathrm{H}, J=7.4, \operatorname{Ar}-H), 6.98-6.96(\mathrm{~m}, 3 \mathrm{H}, \mathrm{Ar}-\mathrm{H}), 7.04$ (d, 2H, $J=$ 7.5, Ar- $H), 7.44(\mathrm{~d}, 1 \mathrm{H}, J=7.7, \mathrm{Ar}-H) .{ }^{51} \mathrm{~V}$ NMR $\left(\mathrm{C}_{6} \mathrm{D}_{6}\right): \delta 519$ $\left(\Delta \nu_{1 / 2}=400 \mathrm{~Hz}\right) .{ }^{13} \mathrm{C} \mathrm{NMR}\left(\mathrm{C}_{6} \mathrm{D}_{6}\right): \delta 2.0\left(\mathrm{SiMe}_{3}\right), 18.9(2-$ $\left.\mathrm{MeC}_{6} \mathrm{H}_{4}\right), 23.6\left(\mathrm{Me}_{2} \mathrm{CH}-\right), 27.0\left(\mathrm{Me}_{2} \mathrm{CH}-\right), 123.3,123.5$, $125.9,126.5,134.1,137.4,137.6,150.5,159.8$ (Ar). Anal. calcd for $\mathrm{C}_{27} \mathrm{H}_{46} \mathrm{NOSi}_{2} \mathrm{~V}$ : C, 63.86; H, 9.13; N, 2.76. Found: C, 63.63; $\mathrm{H}, 9.35$; N, 2.80 .

Synthesis of $\mathrm{V}\left(\mathrm{N}-2-\mathrm{MeC}_{6} \mathrm{H}_{4}\right)\left(\mathrm{CH}_{2} \mathrm{SiMe}_{3}\right)_{2}\left(\mathrm{O}-2-{ }^{t} \mathrm{BuC}_{6} \mathrm{H}_{4}\right)(2 e)$. Synthesis of $2 \mathrm{e}$ was carried out by the same procedure as that for 2a except that $\mathrm{V}\left(\mathrm{N}-2-\mathrm{MeC}_{6} \mathrm{H}_{4}\right)\left(\mathrm{CH}_{2} \mathrm{SiMe}_{3}\right)_{3}(307 \mathrm{mg}, 0.735$ mmol) was used and $2-{ }^{t} \mathrm{BuC}_{6} \mathrm{H}_{4} \mathrm{OH}(112 \mathrm{mg}, 0.746 \mathrm{mmol})$ was added in the place of 2,6- $\mathrm{F}_{2} \mathrm{C}_{6} \mathrm{H}_{3} \mathrm{OH}$. Yield: $324 \mathrm{mg}(92 \%) .{ }^{1} \mathrm{H}$ $\operatorname{NMR}\left(\mathrm{C}_{6} \mathrm{D}_{6}\right): \delta 0.10\left(\mathrm{~s}, 18 \mathrm{H}, \mathrm{CH}_{2} \mathrm{SiMe}_{3}\right), 1.70\left(\mathrm{~s}, 9 \mathrm{H},{ }^{t} \mathrm{Bu}\right)$, 2.25 (br, $2 \mathrm{H}, \mathrm{CH}_{2} \mathrm{SiMe}_{3}$ ), 2.60 (s, 3H, Ar-Me), 2.68 (br, $2 \mathrm{H}$, $\left.\mathrm{CH}_{2} \mathrm{SiMe}_{3}\right), 6.79-6.87(\mathrm{~m}, 2 \mathrm{H}, \mathrm{Ar}-\mathrm{H}), 6.87(\mathrm{t}, 1 \mathrm{H}, J=7.2$, Ar$H), 6.95-7.00(\mathrm{~m}, 2 \mathrm{H}, \mathrm{Ar}-\mathrm{H}), 7.09$ (d, $1 \mathrm{H}, J=7.8, \mathrm{Ar}-H), 7.25$ $(\mathrm{d}, 1 \mathrm{H}, J=7.5, \mathrm{Ar}-\mathrm{H}), 7.61$ (d, $1 \mathrm{H}, J=7.8, \mathrm{Ar}-H) .{ }^{51} \mathrm{~V}$ NMR $\left(\mathrm{C}_{6} \mathrm{D}_{6}\right): \delta 509\left(\Delta \nu_{1 / 2}=320 \mathrm{~Hz}\right) \cdot{ }^{13} \mathrm{C} \mathrm{NMR}\left(\right.$ in $\left.\mathrm{C}_{6} \mathrm{D}_{6}\right): \delta 1.7$ $\left(\mathrm{SiMe}_{3}\right), 18.8\left(2-\mathrm{MeC}_{6} \mathrm{H}_{4}\right), 30.1\left(\mathrm{Me}_{3} \mathrm{C}-\right), 34.9\left(\mathrm{Me}_{3} \mathrm{C}-\right)$, $122.9,123.1,125.7,126.1,126.2,126.4,127.2,130.2,133.9$, 135.3, 162.8 (Ar). Anal. calcd for $\mathrm{C}_{25} \mathrm{H}_{42} \mathrm{NOSi}_{2} \mathrm{~V}: \mathrm{C}, 62.59 ; \mathrm{H}$, 8.82; N, 2.92. Found(1): C, 61.45; H, 8.62; N, 2.96. Found(2): $\mathrm{C}, 60.99 ; \mathrm{H}, 8.59 ; \mathrm{N}, 3.03$. The observed $\mathrm{C}$ values were somewhat low because of the incomplete combustion (by production of vanadium carbide), whereas both $\mathrm{H}$ and $\mathrm{N}$ observed values were close to the calculated values.
Synthesis of $\mathrm{V}\left(\mathrm{N}-2,6-\mathrm{Me}_{2} \mathrm{C}_{6} \mathrm{H}_{3}\right)\left(\mathrm{CH}_{2} \mathrm{SiMe}_{3}\right)_{2}\left(\mathrm{O}-2,6-\mathrm{Cl}_{2} \mathrm{C}_{6} \mathrm{H}_{3}\right)$ (3b). Into an $n$-hexane solution $(30 \mathrm{~mL})$ containing $\mathrm{V}(\mathrm{N}-2,6-$ $\left.\mathrm{Me}_{2} \mathrm{C}_{6} \mathrm{H}_{3}\right)\left(\mathrm{CH}_{2} \mathrm{SiMe}_{3}\right)_{3}(326 \mathrm{mg}, 0.755 \mathrm{mmol})$ was added 2,6$\mathrm{Cl}_{2} \mathrm{C}_{6} \mathrm{H}_{3} \mathrm{OH}(133 \mathrm{mg}, 0.816 \mathrm{mmol})$ at $-30{ }^{\circ} \mathrm{C}$. The solution was stirred at room temperature for $5 \mathrm{~h}$. The resultant solution was placed into a rotary evaporator to remove volatiles, affording a sticky brown liquid. Yield: $380 \mathrm{mg}(99 \%) .{ }^{1} \mathrm{H}$ NMR $\left(\mathrm{C}_{6} \mathrm{D}_{6}\right): \delta$ $0.20\left(\mathrm{~s}, 18 \mathrm{H}, \mathrm{CH}_{2} \mathrm{SiMe}_{3}\right), 2.45$ (d, 2H, $\left.\mathrm{J}=10.5, \mathrm{CH}_{2} \mathrm{SiMe}_{3}\right), 2.53$ $\left(\mathrm{s}, 6 \mathrm{H}, \mathrm{Ar}-\mathrm{Me}_{2}\right), 2.83\left(\mathrm{~d}, 2 \mathrm{H}, \mathrm{J}=10.9, \mathrm{CH}_{2} \mathrm{SiMe}_{3}\right), 6.18(\mathrm{t}, 1 \mathrm{H}, J$ $=8.1, \operatorname{Ar}-H), 6.70(\mathrm{t}, 1 \mathrm{H}, J=7.5, \mathrm{Ar}-H), 6.81(\mathrm{~d}, 2 \mathrm{H}, J=7.5, \mathrm{Ar}-$ $H), 6.88(\mathrm{~d}, 2 \mathrm{H}, J=8.1, \operatorname{Ar}-H) .{ }^{51} \mathrm{~V} \operatorname{NMR}\left(\mathrm{C}_{6} \mathrm{D}_{6}\right): \delta 633\left(\Delta \nu_{1 / 2}\right.$ $=400 \mathrm{~Hz}) .{ }^{13} \mathrm{C} \operatorname{NMR}\left(\mathrm{C}_{6} \mathrm{D}_{6}\right): \delta 1.7\left(\mathrm{SiMe}_{3}\right), 19.3(\mathrm{Ar}-\mathrm{Me})$, $121.9,125.6,126.1,127.9,128.4,129.7,130.0,135.9,157.3$, 157.8 (Ar).

Synthesis of $\mathrm{V}\left(\mathrm{N}-2,6-\mathrm{Me}_{2} \mathrm{C}_{6} \mathrm{H}_{3}\right)\left(\mathrm{CH}_{2} \mathrm{SiMe}_{3}\right)_{2}\left(\mathrm{O}-2-{ }^{t}{ }^{\mathrm{Bu}} \mathrm{C}_{6} \mathrm{H}_{4}\right)$ (3e). Synthesis of $3 \mathbf{e}$ was carried out by the same procedure as that for $3 \mathbf{b}$ except that $\mathrm{V}\left(\mathrm{N}-2,6-\mathrm{Me}_{2} \mathrm{C}_{6} \mathrm{H}_{3}\right)\left(\mathrm{CH}_{2} \mathrm{SiMe}_{3}\right)_{3}$ (349 $\mathrm{mg}, 0.808 \mathrm{mmol})$ was used and 2,6- ${ }^{t} \mathrm{BuC}_{6} \mathrm{H}_{4} \mathrm{OH}(118 \mathrm{mg}, 0.786$ $\mathrm{mmol}$ ) was added in the place of 2,6- $-\mathrm{Cl}_{2} \mathrm{C}_{6} \mathrm{H}_{3} \mathrm{OH}$. Yield: $387 \mathrm{mg}$ (99\%). ${ }^{1} \mathrm{H}$ NMR $\left(\mathrm{C}_{6} \mathrm{D}_{6}\right): \delta 0.13\left(\mathrm{~s}, 18 \mathrm{H}, \mathrm{CH}_{2} \mathrm{SiMe}_{3}\right), 1.64(\mathrm{~s}$, $\left.9 \mathrm{H},{ }^{t} \mathrm{Bu}\right), 2.17$ (br, $\left.2 \mathrm{H}, \mathrm{CH}_{2} \mathrm{SiMe}_{3}\right), 2.56(\mathrm{~s}, 6 \mathrm{H}, \mathrm{Ar}-\mathrm{Me}), 2.75$ (br, $\left.2 \mathrm{H}, \mathrm{CH}_{2} \mathrm{SiMe}_{3}\right), 6.72-6.77(\mathrm{~m}, 3 \mathrm{H}, \mathrm{Ar}-\mathrm{H}), 6.82(\mathrm{~d}, 1 \mathrm{H}, \mathrm{J}=$ 7.9, Ar-H), 6.85 (d, 2H, $J=7.5$, Ar-H), 7.20 (d, 1H, $J=7.4$, Ar$H) .{ }^{51} \mathrm{~V}$ NMR $\left(\mathrm{C}_{6} \mathrm{D}_{6}\right): \delta 518\left(\Delta \nu_{1 / 2}=385 \mathrm{~Hz}\right) .{ }^{13} \mathrm{C} \mathrm{NMR}$ $\left(\mathrm{C}_{6} \mathrm{D}_{6}\right): \delta 2.0$ ( $\left.\mathrm{SiMe}_{3}\right), 19.4$ ( $\left.\mathrm{Ar}-\mathrm{Me}\right), 30.3$ (Me $\mathrm{C}-$ ), 35.1 $\left(\mathrm{Me}_{3} \mathrm{C}-\right)$, 123.2, 123.7, 125.7, 126.6, 127.4, 129.0, 135.2, 135.7, 163.6 (Ar). Anal. calcd for $\mathrm{C}_{26} \mathrm{H}_{44} \mathrm{NOSi}_{2} \mathrm{~V}: \mathrm{C}, 63.25 ; \mathrm{H}, 8.98 ; \mathrm{N}$, 2.84. Found: C, 63.05; H, 8.88; N, 2.95 .

Synthesis of $\mathrm{V}\left(\mathrm{N}-2,6-\mathrm{Cl}_{2} \mathrm{C}_{6} \mathrm{H}_{3}\right) \mathrm{Cl}_{3} \cdot \mathrm{VOCl}_{3}$ (4.18 g, 24.1 $\mathrm{mmol})$ was added into a $n$-octane $(50 \mathrm{~mL})$ solution containing 2,6-dichlorophenyl isocyanate $(2.73 \mathrm{~g}, 14.5 \mathrm{mmol})$ in a sealed Schlenk tube in the drybox. After washing the tube with $n$-octane $(5 \mathrm{~mL})$, the mixture was heated in an oil bath at $140{ }^{\circ} \mathrm{C}$ and the mixture was stirred overnight $(17 \mathrm{~h})$. During the reaction especially at the beginning, the $\mathrm{CO}_{2}$ by-product was carefully removed from the mixture through a nitrogen line. After the reaction, the mixture was cooled at room temperature and was filtered through a celite pad. The filter cake was washed with $n$ hexane to extract $\mathrm{VCl}_{3}\left(\mathrm{~N}-2,6-\mathrm{Cl}_{2} \mathrm{C}_{6} \mathrm{H}_{3}\right)$. Combined, the filtrate and wash liquid were added to toluene and placed in vacuo to remove volatiles. The resultant solid was dissolved in a minimum amount of dichloromethane, and the chilled solution $\left(-30^{\circ} \mathrm{C}\right)$ afforded a deep green solid $(4.43 \mathrm{~g}, 14.0 \mathrm{mmol})$. Yield: 97\% (based on 2,6-dichlorophenyl isocyanate). ${ }^{1} \mathrm{H}$ NMR $\left(\mathrm{C}_{6} \mathrm{D}_{6}\right): \delta 5.79(\mathrm{t}, 1 \mathrm{H}, J=7.5, \mathrm{Ar}-\mathrm{H}), 6.27(\mathrm{~d}, 2 \mathrm{H}, J=7.5, \mathrm{Ar}-$ $\mathrm{H}) .{ }^{51} \mathrm{~V}$ NMR $\left(\mathrm{C}_{6} \mathrm{D}_{6}\right): \delta 262\left(\Delta \nu_{1 / 2}=354 \mathrm{~Hz}\right) \cdot{ }^{13} \mathrm{C} \mathrm{NMR}$ $\left(\mathrm{C}_{6} \mathrm{D}_{6}\right): \delta 127.6,131.2,135.4,165.6$. Anal. calcd for $\mathrm{C}_{6} \mathrm{H}_{3} \mathrm{Cl}_{5} \mathrm{NV}$ : C, 22.71; H, 0.95; N, 4.41. Found: C, 23.01; H, $0.91 ; \mathrm{N}, 4.50$.

Synthesis of $\mathrm{V}\left(\mathrm{N}-2,6-\mathrm{Cl}_{2} \mathrm{C}_{6} \mathrm{H}_{3}\right)\left(\mathrm{CH}_{2} \mathrm{SiMe}_{3}\right)_{3}$. Into a tetrahydrofuran solution $(60 \mathrm{~mL})$ containing $\mathrm{LiCH}_{2} \mathrm{SiMe}_{3}(2.08 \mathrm{~g}, 22.1$ $\mathrm{mmol})$ was added $\mathrm{V}\left(\mathrm{N}-2,6-\mathrm{Cl}_{2} \mathrm{C}_{6} \mathrm{H}_{3}\right) \mathrm{Cl}_{3}(2.27 \mathrm{mg}, 7.16 \mathrm{mmol})$ at $-30{ }^{\circ} \mathrm{C}$. The solution was stirred at room temperature for $3 \mathrm{~h}$. The resultant solution was filtered through a celite pad and the filter cake was washed with $n$-hexane. Combined, the filtrate and the wash liquid were placed into a rotary evaporator to remove volatiles, affording a sticky brown liquid. Yield: $2.35 \mathrm{mg}(70 \%)$. ${ }^{1} \mathrm{H}$ NMR $\left(\mathrm{C}_{6} \mathrm{D}_{6}\right): \delta 0.17\left(\mathrm{~s}, 18 \mathrm{H}, \mathrm{CH}_{2} \mathrm{SiMe} e_{3}\right), 2.22(\mathrm{br}, 6 \mathrm{H}$, $\mathrm{CH}_{2} \mathrm{SiMe}_{3}$ ), $6.22(\mathrm{t}, 1 \mathrm{H}, J=8.0, \mathrm{Ar}-\mathrm{H}), 6.97$ (d, $1 \mathrm{H}, J=8.1, \mathrm{Ar}-$ $H) .{ }^{51} \mathrm{~V}$ NMR $\left(\mathrm{C}_{6} \mathrm{D}_{6}\right): \delta 1162 .{ }^{13} \mathrm{C}$ NMR $\left(\mathrm{C}_{6} \mathrm{D}_{6}\right): \delta 2.36$ $\left(\mathrm{SiMe}_{3}\right), 93.0-96.8$ (br, V-CH$\left.{ }_{2}\right), 124.7,125.1,126.6,128.5$, 131.9, 158.6 (Ar). Anal. calcd for $\mathrm{C}_{18} \mathrm{H}_{36} \mathrm{Cl}_{2} \mathrm{NOSi}_{3} \mathrm{~V}$ : C, 45.75; H, 7.68; N, 2.96. Found: C, 45.53; H, 7.52; N, 2.86. 
Synthesis of $\mathrm{V}\left(\mathrm{N}-2,6-\mathrm{Cl}_{2} \mathrm{C}_{6} \mathrm{H}_{3}\right)\left(\mathrm{CH}_{2} \mathrm{SiMe}_{3}\right)_{2}\left(\mathrm{O}-2,6-\mathrm{F}_{2} \mathrm{C}_{6} \mathrm{H}_{3}\right)$ (4a). Into an $n$-hexane solution $(30 \mathrm{~mL})$ containing $\mathrm{V}(\mathrm{N}-2,6-$ $\left.\mathrm{Cl}_{2} \mathrm{C}_{6} \mathrm{H}_{3}\right)\left(\mathrm{CH}_{2} \mathrm{SiMe}_{3}\right)_{3}(300 \mathrm{mg}, 0.635 \mathrm{mmol})$ was added 2,6$\mathrm{F}_{2} \mathrm{C}_{6} \mathrm{H}_{3} \mathrm{OH}(97 \mathrm{mg}, 0.746 \mathrm{mmol})$ at $-30{ }^{\circ} \mathrm{C}$. The solution was warmed slowly to room temperature (total $5 \mathrm{~h}$ ). The resultant mixture was placed into a rotary evaporator to remove volatiles to afford a sticky brown liquid. Yield: $272 \mathrm{mg}(83 \%) .{ }^{1} \mathrm{H}$ NMR $\left(\mathrm{C}_{6} \mathrm{D}_{6}\right): \delta 0.19$ (s, $\left.18 \mathrm{H}, \mathrm{CH}_{2} \mathrm{SiMe}_{3}\right), 2.93\left(\mathrm{br}, 2 \mathrm{H}, \mathrm{CH}_{2} \mathrm{SiMe}_{3}\right)$, $3.14\left(\mathrm{br}, 2 \mathrm{H}, \mathrm{CH}_{2} \mathrm{SiMe}_{3}\right), 6.14(\mathrm{t}, 1 \mathrm{H}, J=8.1, \mathrm{Ar}-\mathrm{H}), 6.25(\mathrm{~m}$, $1 \mathrm{H}, \mathrm{Ar}-\mathrm{H}), 6.52(\mathrm{t}, 2 \mathrm{H}, J=7.8, \mathrm{Ar}-\mathrm{H}), 6.82(\mathrm{~d}, 2 \mathrm{H}, J=8.1, \mathrm{Ar}-$ $H) .{ }^{51} \mathrm{~V}$ NMR $\left(\mathrm{C}_{6} \mathrm{D}_{6}\right): \delta 657\left(\Delta \nu_{1 / 2}=287 \mathrm{~Hz}\right) \cdot{ }^{13} \mathrm{C} \mathrm{NMR}$ $\left(\mathrm{C}_{6} \mathrm{D}_{6}\right): \delta 1.4\left(\mathrm{SiMe}_{3}\right), 111.6\left(\mathrm{dd},{ }^{2} J_{\mathrm{C}-\mathrm{F}}=16.7,{ }^{4} J_{\mathrm{C}-\mathrm{F}}=5.7\right)$, $120.2\left(\mathrm{t},{ }^{3} J_{\mathrm{C}-\mathrm{F}}=8.9\right), 125.6,132.6,154.1\left(\mathrm{dd},{ }^{1} J_{\mathrm{C}-\mathrm{F}}=247,{ }^{3} J_{\mathrm{C}-\mathrm{F}}\right.$ $=4.6), 164.2(\mathrm{Ar}) .{ }^{19} \mathrm{~F}$ NMR $\left(\mathrm{C}_{6} \mathrm{D}_{6}\right): \delta-127.5\left(\mathrm{t},{ }^{4} J_{\mathrm{F}-\mathrm{F}}=6.6\right.$, Ar-F). Anal. calcd for $\mathrm{C}_{20} \mathrm{H}_{28} \mathrm{Cl}_{2} \mathrm{~F}_{2} \mathrm{NOSi}_{2} \mathrm{~V}: \mathrm{C}, 46.69 ; \mathrm{H}, 5.49$; N, 2.72. Found: C, 46.39; H, 5.47; N, 2.86.

Synthesis of $\mathrm{V}\left(\mathrm{N}-2,6-\mathrm{Cl}_{2} \mathrm{C}_{6} \mathrm{H}_{3}\right)\left(\mathrm{CH}_{2} \mathrm{SiMe}_{3}\right)_{2}\left(\mathrm{O}-2,6-\mathrm{Cl}_{2} \mathrm{C}_{6} \mathrm{H}_{3}\right)$ (4b). Synthesis of $\mathbf{4 b}$ was carried out by the same procedure as that for $4 a$ except that $\mathrm{V}\left(\mathrm{N}-2,6-\mathrm{Cl}_{2} \mathrm{C}_{6} \mathrm{H}_{3}\right)\left(\mathrm{CH}_{2} \mathrm{SiMe}_{3}\right)_{3}(248$ $\mathrm{mg}, 0.525 \mathrm{mmol}$ ) was used and $2,6-\mathrm{Cl}_{2} \mathrm{C}_{6} \mathrm{H}_{3} \mathrm{OH}(84 \mathrm{mg}, 0.515$ mmol) was added in the place of 2,6- $\mathrm{F}_{2} \mathrm{C}_{6} \mathrm{H}_{3} \mathrm{OH}$. Yield: $260 \mathrm{mg}$ (91\%). ${ }^{1} \mathrm{H} \mathrm{NMR}\left(\mathrm{C}_{6} \mathrm{D}_{6}\right): \delta 0.22\left(\mathrm{~s}, 18 \mathrm{H}, \mathrm{CH}_{2} \mathrm{SiMe} e_{3}\right), 2.87$ (br, $2 \mathrm{H}, \mathrm{CH}_{2} \mathrm{SiMe}_{3}$ ), 3.19 (br, $\left.2 \mathrm{H}, \mathrm{CH}_{2} \mathrm{SiMe}_{3}\right), 6.13(\mathrm{t}, 1 \mathrm{H}, \mathrm{J}=8.0$, $\operatorname{Ar}-H), 6.19(\mathrm{t}, 1 \mathrm{H}, J=8.0, \mathrm{Ar}-H), 6.82(\mathrm{~d}, 2 \mathrm{H}, J=8.0, \mathrm{Ar}-\mathrm{H})$, $6.89(\mathrm{~d}, 2 \mathrm{H}, J=8.0, \mathrm{Ar}-H) .{ }^{51} \mathrm{~V}$ NMR $\left(\mathrm{C}_{6} \mathrm{D}_{6}\right): \delta 675\left(\Delta \nu_{1 / 2}=\right.$ $487 \mathrm{~Hz}) .{ }^{13} \mathrm{C}$ NMR $\left(\mathrm{C}_{6} \mathrm{D}_{6}\right): \delta 1.6\left(\mathrm{SiMe}_{3}\right), 98.5-100.9(\mathrm{br}, \mathrm{V}-$ $\left.\mathrm{CH}_{2}\right), 122.3,125.6,126.0,128.0,128.3,132.8,144.7,148.1$, 157.4 (Ar). Anal. calcd for $\mathrm{C}_{20} \mathrm{H}_{28} \mathrm{Cl}_{4} \mathrm{NOSi}_{2} \mathrm{~V}: \mathrm{C}, 43.98 ; \mathrm{H}, 5.16$; $\mathrm{N}, 2.56$. Found: C, 44.05; H, 5.04; N, 2.60 .

Synthesis of $\mathrm{V}\left(\mathrm{N}-2,6-\mathrm{Cl}_{2} \mathrm{C}_{6} \mathrm{H}_{3}\right)\left(\mathrm{CH}_{2} \mathrm{SiMe}_{3}\right)_{2}\left(\mathrm{O}-2,6-\mathrm{Me}_{2} \mathrm{C}_{6} \mathrm{H}_{3}\right)$ (4c). Synthesis of $4 \mathrm{c}$ was carried out by the same procedure as that for $4 a$ except that $\mathrm{V}\left(\mathrm{N}-2,6-\mathrm{Me}_{2} \mathrm{C}_{6} \mathrm{H}_{3}\right)\left(\mathrm{CH}_{2} \mathrm{SiMe}_{3}\right)_{3}(236$ $\mathrm{mg}, 0.499 \mathrm{mmol}$ ) was used and 2,6- $\mathrm{Cl}_{2} \mathrm{C}_{6} \mathrm{H}_{3} \mathrm{OH}(69 \mathrm{mg}, 0.565$ mmol) was added in the place of 2,6- $\mathrm{F}_{2} \mathrm{C}_{6} \mathrm{H}_{3} \mathrm{OH}$. Yield: $248 \mathrm{mg}$ (98\%). ${ }^{1} \mathrm{H}$ NMR $\left(\mathrm{C}_{6} \mathrm{D}_{6}\right): \delta 0.20\left(\mathrm{~s}, 18 \mathrm{H}, \mathrm{CH}_{2} \mathrm{SiMe}_{3}\right), 2.28(\mathrm{~s}$, $6 \mathrm{H}, \mathrm{Ar}-\mathrm{Me}$ ), 2.40 (br, 2H, $\left.\mathrm{CH}_{2} \mathrm{SiMe}_{3}\right), 2.94$ (br, 2H, $\left.\mathrm{CH}_{2} \mathrm{SiMe}_{3}\right), 6.14(\mathrm{t}, 1 \mathrm{H}, J=8.1, \mathrm{Ar}-\mathrm{H}), 6.77(\mathrm{t}, 1 \mathrm{H}, J=7.5$, Ar-H), $6.83(\mathrm{~d}, 2 \mathrm{H}, J=8.1, \mathrm{Ar}-H), 6.90(\mathrm{~d}, 2 \mathrm{H}, J=7.4, \mathrm{Ar}-H)$. ${ }^{51} \mathrm{~V} \mathrm{NMR}\left(\mathrm{C}_{6} \mathrm{D}_{6}\right): \delta 577\left(\Delta \nu_{1 / 2}=342 \mathrm{~Hz}\right) \cdot{ }^{13} \mathrm{C} \operatorname{NMR}\left(\mathrm{C}_{6} \mathrm{D}_{6}\right): \delta$ $1.7\left(\mathrm{SiMe}_{3}\right), 17.6$ (Ar-Me), 122.8, 125.2, 127.4, 127.9, 128.3, 128.6, 132.4, 164.2 (Ar). Anal. calcd for $\mathrm{C}_{22} \mathrm{H}_{34} \mathrm{Cl}_{2} \mathrm{NOSi}_{2} \mathrm{~V}: \mathrm{C}$, 52.17; H, 6.77; N, 2.77. Found (1): C, 51.78; H, 6.71; N, 2.71. Found(2): C, 51.64; H, 6.51; N, 2.64. The observed $\mathrm{C}$ values were somewhat low because of the incomplete combustion (by production of vanadium carbide), whereas both $\mathrm{H}$ and $\mathrm{N}$ observed values were close to the calculated values.

Synthesis of $\mathrm{V}\left(\mathrm{N}-2,6-\mathrm{Cl}_{2} \mathrm{C}_{6} \mathrm{H}_{3}\right)\left(\mathrm{CH}_{2} \mathrm{SiMe}_{3}\right)_{2}\left(\mathrm{O}-2,6-{ }^{i} \mathrm{Pr}_{2} \mathrm{C}_{6} \mathrm{H}_{3}\right)$ (4d). Synthesis of $4 d$ was carried out by the same procedure as that for $4 a$ except that $\mathrm{V}\left(\mathrm{N}-2,6-\mathrm{Cl}_{2} \mathrm{C}_{6} \mathrm{H}_{3}\right)\left(\mathrm{CH}_{2} \mathrm{SiMe}_{3}\right)_{3}(237$ $\mathrm{mg}, 0.549 \mathrm{mmol})$ was used and 2,6- ${ }^{i} \mathrm{Pr}_{2} \mathrm{C}_{6} \mathrm{H}_{3} \mathrm{OH}(109 \mathrm{mg}, 0.611$ mmol) was added in the place of $2,6-\mathrm{F}_{2} \mathrm{C}_{6} \mathrm{H}_{3} \mathrm{OH}$ and the mixture was stirred overnight. Yield: $278 \mathrm{mg}(90 \%) .{ }^{1} \mathrm{H}$ NMR $\left(\mathrm{C}_{6} \mathrm{D}_{6}\right): \delta 0.26$ (s, $\left.18 \mathrm{H}, \mathrm{CH}_{2} \mathrm{SiMe}_{3}\right), 1.21\left(\mathrm{~d}, 12 \mathrm{H}, J=6.9,{ }^{i} \mathrm{Pr}\right)$, 2.45 (d, $2 \mathrm{H}, J=10.4, \mathrm{CH}_{2} \mathrm{SiMe}_{3}$ ), 2.86 (d, $2 \mathrm{H}, J=10.2$, $\mathrm{CH}_{2} \mathrm{SiMe}_{3}$ ), 3.52 (sep, $2 \mathrm{H}, J=6.8,{ }^{i} \mathrm{Pr}$ ), $6.13(\mathrm{t}, 1 \mathrm{H}, J=8.1$, Ar$H), 6.81(\mathrm{~d}, 2 \mathrm{H}, J=8.1, \mathrm{Ar}-H), 6.95(\mathrm{t}, 1 \mathrm{H}, J=7.6, \mathrm{Ar}-H), 7.03$ $(\mathrm{d}, 2 \mathrm{H}, J=7.6, \mathrm{Ar}-H) .{ }^{51} \mathrm{~V}$ NMR $\left(\mathrm{C}_{6} \mathrm{D}_{6}\right): \delta 577\left(\Delta \nu_{1 / 2}=362\right.$ $\mathrm{Hz}) .{ }^{13} \mathrm{C}$ NMR $\left(\mathrm{C}_{6} \mathrm{D}_{6}\right): \delta 1.8\left(\mathrm{SiMe}_{3}\right), 23.6\left(\mathrm{Me}_{2} \mathrm{CH}-\right), 27.1$ $\left(\mathrm{Me}_{2} \mathrm{CH}-\right)$, 123.5, 123.7, 125.2, 132.3, 137.8, 162.3 (Ar). Sample for the crystallographic analysis was obtained upon recrystallization.

Synthesis of $\mathrm{V}\left(\mathrm{N}-2,6-\mathrm{Cl}_{2} \mathrm{C}_{6} \mathrm{H}_{3}\right)\left(\mathrm{CH}_{2} \mathrm{SiMe}_{3}\right)_{2}\left(\mathrm{O}-2-{ }^{t} \mathrm{Bu} \mathrm{C}_{6} \mathrm{H}_{4}\right)$ (4e). Synthesis of $4 \mathrm{e}$ was carried out by the same procedure as that for 4a except that $\mathrm{V}\left(\mathrm{N}-2,6-\mathrm{Cl}_{2} \mathrm{C}_{6} \mathrm{H}_{3}\right)\left(\mathrm{CH}_{2} \mathrm{SiMe}_{3}\right)_{3}$ (299 $\mathrm{mg}, 0.633 \mathrm{mmol}$ ) was used and 2,6- ${ }^{t} \mathrm{BuC}_{6} \mathrm{H}_{4} \mathrm{OH}(111 \mathrm{mg}, 0.739$ $\mathrm{mmol}$ ) was added in the place of $2,6-\mathrm{F}_{2} \mathrm{C}_{6} \mathrm{H}_{3} \mathrm{OH}$. Yield: $372 \mathrm{mg}$ (99\%). ${ }^{1} \mathrm{H}$ NMR $\left(\mathrm{C}_{6} \mathrm{D}_{6}\right): \delta 0.13\left(\mathrm{~s}, 18 \mathrm{H}, \mathrm{CH}_{2} \mathrm{SiMe}_{3}\right), 1.72$ (s, $9 \mathrm{H},{ }^{t} \mathrm{Bu}$ ), 2.86 (br, $2 \mathrm{H}, \mathrm{CH}_{2} \mathrm{SiMe}_{3}$ ), 2.93 (br, $2 \mathrm{H}, \mathrm{CH}_{2} \mathrm{SiMe}_{3}$ ), $6.19(\mathrm{t}, 1 \mathrm{H}, J=8.1, \mathrm{Ar}-H), 6.81(\mathrm{t}, 1 \mathrm{H}, J=7.6, \mathrm{Ar}-H), 6.89(\mathrm{~m}$, $3 \mathrm{H}, \mathrm{Ar}-\mathrm{H}), 7.05$ (d, $1 \mathrm{H}, J=7.9, \mathrm{Ar}-\mathrm{H}), 7.24$ (d, 1H, $J=7.6, \mathrm{Ar}-$ $H) .{ }^{51} \mathrm{~V}$ NMR $\left(\mathrm{C}_{6} \mathrm{D}_{6}\right): \delta 584\left(\Delta \nu_{1 / 2}=316 \mathrm{~Hz}\right) \cdot{ }^{13} \mathrm{C} \mathrm{NMR}$ $\left(\mathrm{C}_{6} \mathrm{D}_{6}\right): \delta 1.9\left(\mathrm{SiMe}_{3}\right), 30.5\left(\mathrm{Me}_{3} \mathrm{C}-\right), 35.2\left(\mathrm{Me}_{3} \mathrm{C}-\right)$, 123.6, 124.7, 125.2, 126.5, 127.4, 132.2, 165.4 (Ar).

NMR Experiments for Time Course in the Reaction of $\mathrm{V}\left(\mathrm{NAr}^{\prime}\right)\left(\mathrm{CH}_{2} \mathrm{SiMe}_{3}\right)_{3}\left(\mathrm{Ar}^{\prime}=\mathrm{C}_{6} \mathrm{H}_{5}, 2-\mathrm{MeC}_{6} \mathrm{H}_{4}, 2,6-\mathrm{Me}_{2} \mathrm{C}_{6} \mathrm{H}_{3}, 2,6-\right.$ $\mathrm{Cl}_{2} \mathrm{C}_{6} \mathrm{H}_{3}$ ) with $\mathrm{ArOH}\left(\mathrm{Ar}=2,6-\mathrm{F}_{2} \mathrm{C}_{6} \mathrm{H}_{3}, 2,6-\mathrm{Cl}_{2} \mathrm{C}_{6} \mathrm{H}_{3}, 2,6-\right.$ $\left.\mathrm{Me}_{2} \mathrm{C}_{6} \mathrm{H}_{3}, 2,6-{ }^{i} \mathrm{Pr}_{2} \mathrm{C}_{6} \mathrm{H}_{3},{ }^{2}-{ }^{t} \mathrm{BuC}_{6} \mathrm{H}_{4}\right)$ in $\mathrm{C}_{6} \mathrm{D}_{6}$. The typical procedure is as follows. Into a $\mathrm{C}_{6} \mathrm{D}_{6}$ solution (ca. $0.6 \mathrm{~mL}$ ) containing $\mathrm{V}\left(\mathrm{NC}_{6} \mathrm{H}_{5}\right)\left(\mathrm{CH}_{2} \mathrm{SiMe}_{3}\right)_{3}(20.2 \mathrm{mg}, 50 \mu \mathrm{mol})$, a $\mathrm{C}_{6} \mathrm{D}_{6}$ solution (ca. $0.4 \mathrm{~mL}$ ) containing $2,6-\mathrm{F}_{2} \mathrm{C}_{6} \mathrm{H}_{3} \mathrm{OH}(6.5 \mathrm{mg}$, 1.0 equiv) was added at $25^{\circ} \mathrm{C}$. The mixture was then monitored by both ${ }^{1} \mathrm{H}$ and ${ }^{51} \mathrm{~V}$ NMR spectra after a certain period (10 and $40 \mathrm{~min}$ ) to estimate the ratio (conversion) by the integration ratio of the starting material and the product.

NMR Experiments for Time Course in the Reaction of $V\left(\mathrm{NAr}^{\prime}\right)\left(\mathrm{CH}_{2} \mathrm{SiMe}_{3}\right)_{3}\left(\mathrm{Ar}^{\prime}=\mathrm{C}_{6} \mathrm{H}_{5}, 2-\mathrm{MeC}_{6} \mathrm{H}_{4}, 2,6-\mathrm{Me}_{2} \mathrm{C}_{6} \mathrm{H}_{3}\right.$ 2,6$\mathrm{Cl}_{2} \mathrm{C}_{6} \mathrm{H}_{3}$ ) with $2,6-^{t} \mathrm{Bu}_{2} \mathrm{C}_{6} \mathrm{H}_{3} \mathrm{OH}$ in $\mathrm{C}_{6} \mathrm{D}_{6}$. Typical procedure is as follows:

(i) Reaction of $\mathrm{V}\left(\mathrm{NC}_{6} \mathrm{H}_{5}\right)\left(\mathrm{CH}_{2} \mathrm{SiMe}_{3}\right)_{3}$ with 1.0 equiv of 2,6- ${ }^{t} \mathrm{Bu}_{2} \mathrm{C}_{6} \mathrm{H}_{3} \mathrm{OH}$ at $25-60{ }^{\circ} \mathrm{C}$. Into a $\mathrm{C}_{6} \mathrm{D}_{6}$ solution (0.4 $\mathrm{mL})$ containing $\mathrm{V}\left(\mathrm{NC}_{6} \mathrm{H}_{5}\right)\left(\mathrm{CH}_{2} \mathrm{SiMe}_{3}\right)_{3}(11 \mathrm{mg}, 0.05$ $\mathrm{mmol})$ in J. Young NMR tubes, a $\mathrm{C}_{6} \mathrm{D}_{6}$ solution $(0.4 \mathrm{~mL})$ containing 2,6- ${ }^{t} \mathrm{Bu}_{2} \mathrm{C}_{6} \mathrm{H}_{3} \mathrm{OH}(21 \mathrm{mg}, 0.05 \mathrm{mmol})$ was added slowly at room temperature. The reaction mixture was monitored by ${ }^{1} \mathrm{H}$ and ${ }^{51} \mathrm{~V}$ NMR at $20 \mathrm{~min}, 17 \mathrm{~h}$, and 4 days. Then, the reaction mixture was heated at $60{ }^{\circ} \mathrm{C}$ and monitored by NMR spectra at 9, 31, and $50 \mathrm{~h}$. The spectra are shown in the Supporting Information. ${ }^{b}$

(ii) Reaction of $\mathrm{V}\left(\mathrm{NC}_{6} \mathrm{H}_{5}\right)\left(\mathrm{CH}_{2} \mathrm{SiMe}_{3}\right)_{3}$ with 3.0 equiv of 2,6- ${ }^{t} \mathrm{Bu}_{2} \mathrm{C}_{6} \mathrm{H}_{3} \mathrm{OH}$ at $25-60{ }^{\circ} \mathrm{C}$. The reaction was conducted similar to the reaction with 1.0 equiv of 2,6- ${ }^{t} \mathrm{Bu}_{2} \mathrm{C}_{6} \mathrm{H}_{3} \mathrm{OH}$ except that the reaction was conducted at $25{ }^{\circ} \mathrm{C}$ for 6 days. The resultant mixture was monitored by ${ }^{1} \mathrm{H}$ NMR spectrum in $\mathrm{C}_{6} \mathrm{D}_{6}$. The spectra are shown in the Supporting Information. ${ }^{b}$

\section{ASSOCIATED CONTENT}

\section{Supporting Information}

The Supporting Information is available free of charge on the ACS Publications website at DOI: 10.1021/acsomega.9b00531.

Selected NMR spectra for $\left(\mathrm{NAr}^{\prime}\right)\left(\mathrm{CH}_{2} \mathrm{SiMe}_{3}\right)_{2}(\mathrm{OAr})$ [1a-e, 2a-e, 3b,e, 4a-e; $\mathrm{Ar}^{\prime}=\mathrm{C}_{6} \mathrm{H}_{5}(\mathbf{1}), 2-\mathrm{MeC}_{6} \mathrm{H}_{4}(\mathbf{2})$, 2,6- $\mathrm{Me}_{2} \mathrm{C}_{6} \mathrm{H}_{3}$ (3), 2,6- $\mathrm{Cl}_{2} \mathrm{C}_{6} \mathrm{H}_{3}(4) ; \mathrm{Ar}=2,6-\mathrm{F}_{2} \mathrm{C}_{6} \mathrm{H}_{3}$ (a), 2,6- $\mathrm{Cl}_{2} \mathrm{C}_{6} \mathrm{H}_{3}$ (b), 2,6- $\mathrm{Me}_{2} \mathrm{C}_{6} \mathrm{H}_{3}$ (c), 2,6- ${ }^{i} \mathrm{Pr}_{2} \mathrm{C}_{6} \mathrm{H}_{3}$ (d), $\left.2-{ }^{t} \mathrm{BuC}_{6} \mathrm{H}_{4}(\mathrm{e})\right], \mathrm{V}\left(\mathrm{N}-2-\mathrm{MeC}_{6} \mathrm{H}_{4}\right)\left(\mathrm{CH}_{2} \mathrm{SiMe}_{3}\right)_{3}, \mathrm{~V}(\mathrm{~N}-$ 2,6- $\left.-\mathrm{Cl}_{2} \mathrm{C}_{6} \mathrm{H}_{3}\right)\left(\mathrm{CH}_{2} \mathrm{SiMe}_{3}\right)_{3}$, and $\mathrm{V}\left(\mathrm{N}-2,6-\mathrm{Cl}_{2} \mathrm{C}_{6} \mathrm{H}_{3}\right) \mathrm{Cl}_{3}$; selected NMR spectra for monitoring the reaction of $\mathrm{V}\left(\mathrm{NAr}^{\prime}\right)\left(\mathrm{CH}_{2} \mathrm{SiMe}_{3}\right)_{3}$ with ArOH (PDF)

Crystallographic analysis procedure, oak ridge thermal ellipsoid plot drawings and selected bond distances and angles, CIF and xyz files for $\mathrm{V}\left(\mathrm{N}-2,6-\mathrm{Cl}_{2} \mathrm{C}_{6} \mathrm{H}_{3}\right)$ $\left(\mathrm{CH}_{2} \mathrm{SiMe}_{3}\right)_{2}\left(\mathrm{O}-2,6-{ }^{i} \mathrm{Pr}_{2} \mathrm{C}_{6} \mathrm{H}_{3}\right)$ (4d, CCDC 1879594); computed Cartesian coordinates of all of the molecules for complex $\mathbf{4 d}$ reported in this study (CIF) 
Files to be opened as a text file to read the coordinates or directly by a molecular modeling program such as Mercury (version 3.3 or later, http://www.ccdc.cam.ac. uk/pages/Home.aspx) for visualization and analysis (TXT)

\section{AUTHOR INFORMATION}

\section{Corresponding Author}

*E-mail: ktnomura@tmu.ac.jp. Tel.: +81-42-677-2547. Fax: $+81-42-677-2547$.

\section{ORCID $\odot$}

Kotohiro Nomura: 0000-0003-3661-6328

\section{Present Address}

${ }^{\dagger}$ Warren and Katharine Schlinger Laboratory for Chemistry and Chemical Engineering, Division of Chemistry and Chemical Engineering, California Institute of Technology, 1200 East California Boulevard, MC 101-20, Pasadena, California 91125, United States (A.N.).

\section{Notes}

The authors declare no competing financial interest.

\section{ACKNOWLEDGMENTS}

This project was partly supported by Grant-in-Aid for Scientific Research on Innovative Areas ("3D Active-Site Science", No. 26105003) from the Ministry of Education, Culture, Sports, Science and Technology (MEXT), Japan, and Grant-in-Aid for Scientific Research from the Japan Society for the Promotion of Science (JSPS, Nos 15H03812 and 18H01982). Authors express their gratitude to Profs. S. Komiya, K. Tsutsumi, and A. Inagaki (Tokyo Metropolitan Univ.) for discussion, and H.H. expresses her thanks to Prof. K. Tsutsumi for help in the crystallographic analysis.

\section{ADDITIONAL NOTES}

${ }^{a}$ Selected NMR spectra for V(NAr') $\left(\mathrm{CH}_{2} \mathrm{SiMe}_{3}\right)_{2}(\mathrm{OAr})[\mathbf{1 a}-$ e, $2 \mathbf{a}-\mathbf{e}, 3 \mathbf{b}, \mathbf{e}, 4 \mathbf{a}-\mathbf{e} ; \mathrm{Ar}^{\prime}=\mathrm{C}_{6} \mathrm{H}_{5}$ (1), 2- $\mathrm{MeC}_{6} \mathrm{H}_{4}$ (2), 2,6$\mathrm{Me}_{2} \mathrm{C}_{6} \mathrm{H}_{3}$ (3), 2,6- $\mathrm{Cl}_{2} \mathrm{C}_{6} \mathrm{H}_{3}$ (4); $\mathrm{Ar}=2,6-\mathrm{F}_{2} \mathrm{C}_{6} \mathrm{H}_{3}$ (a), 2,6$\mathrm{Cl}_{2} \mathrm{C}_{6} \mathrm{H}_{3}$ (b), 2,6- $\mathrm{Me}_{2} \mathrm{C}_{6} \mathrm{H}_{3}$ (c), 2,6- ${ }_{-}^{i} \mathrm{Pr}_{2} \mathrm{C}_{6} \mathrm{H}_{3}$ (d), $2-{ }^{t} \mathrm{BuC}_{6} \mathrm{H}_{4}$ (e) $]$ and structural analysis for $4 \mathbf{d}$, including CIF and xyz files, are shown in the Supporting Information. The crystallographic analysis data was also deposited in the Cambridge Crystallographic Data Centre (CCDC 1879594).

${ }^{b}$ Selected NMR spectra for monitoring the reaction of $\mathrm{V}\left(\mathrm{NAr}^{\prime}\right)\left(\mathrm{CH}_{2} \mathrm{SiMe}_{3}\right)_{3}$ with $\mathrm{ArOH}$ are shown in the Supporting Information. The conversions of $\mathrm{V}\left(\mathrm{NAr}^{\prime}\right)\left(\mathrm{CH}_{2} \mathrm{SiMe}_{3}\right)_{3}$ were estimated on the basis of integration ratios of dialkyl/trialkyl complexes in ${ }^{51} \mathrm{~V}$ NMR spectra, and the ratios in the reaction with 2,6- $\mathrm{Cl}_{2} \mathrm{C}_{6} \mathrm{H}_{3} \mathrm{OH}$ were estimated by ${ }^{1} \mathrm{H}$ NMR spectra.

\section{REFERENCES}

(1) Selected books (refs 1-4), see: The Organometallic Chemistry of the Transition Metals, 6th ed.; Crabtree, R. H.; John Wiley \& Sons, Inc.: Hoboken, NJ, 2014; pp 69-97.

(2) Comprehensive Organometallic Chemistry III; Crabtree, R. H., Mingos, D. M. P., Eds.; Elsevier Science/Pergamon US, 2006.

(3) Astruc, D. Organometallic Chemistry and Catalysis; SpringerVerlag: Berlin Heidelberg, Germany, 2007.

(4) Organotransition Metal Chemistry: From Bonding to Catalysis; Hartwig, J., Ed.; University Science Books, 2010.

(5) Selected early reviews (refs 5-10), see: Brintzinger, H. H.; Fischer, D.; Mülhaupt, R.; Rieger, B.; Waymouth, R. M. A tailor-made metallocene for the copolymerization of ethene with bulky cycloalkenes. Angew. Chem., Int. Ed. 1995, 34, 1143-1170.
(6) Kaminsky, W.; Arndt, M. Metallocenes for polymer catalysis. Advances in Polymer Science; Springer-Verlag: Berlin Heidelberg, Germany, 1997; Vol. 127, pp 144-187.

(7) McKnight, A. L.; Waymouth, R. M. Group 4 ansa-cyclopentadienyl-amido catalysts for olefin polymerization. Chem. Rev. 1998, 98, 2587-2598.

(8) Britovsek, G. J. P.; Gibson, V. C.; Wass, D. F. The search for newgeneration olefin polymerization catalysts: Life beyond metallocenes. Angew. Chem., Int. Ed. 1999, 38, 428-447.

(9) Coates, G. W.; Hustad, P. D.; Reinartz, S. Catalysts for the living insertion polymerization of alkenes: access to new polyolefin architectures using Ziegler-Natta chemistry. Angew. Chem., Int. Ed. 2002, 41, 2236-2257.

(10) Gibson, V. C.; Spitzmesser, S. K. Advances in non-metallocene olefin polymerization catalysis. Chem. Rev. 2003, 103, 283-316.

(11) Selected recent reviews/accounts (refs 11-18), see: Organometallic Reactions and Polymerization; Osakada, K. Ed.; The Lecture Notes in Chemistry 85; Springer-Verlag: Berlin, 2014.

(12) Nomura, K.; Zhang, S. Design of vanadium complex catalysts for precise olefin polymerization. Chem. Rev. 2011, 111, 2342-2362.

(13) Makio, H.; Terao, H.; Iwashita, A.; Fujita, T. FI Catalysts for olefin polymerization-A comprehensive treatment. Chem. Rev. 2011, $111,2363-2449$.

(14) Delferro, M.; Marks, T. J. Multinuclear olefin polymerization catalysts. Chem. Rev. 2011, 111, 2450-2485.

(15) McInnis, J. P.; Delferro, M.; Marks, T. J. Multinuclear group 4 catalysis: Olefin polymerization pathways modified by strong metalmetal cooperative effects. Acc. Chem. Res. 2014, 47, 2545-2557.

(16) Valente, A.; Mortreux, A.; Visseaux, M.; Zinck, P. Coordinative chain transfer polymerization. Chem. Rev. 2013, 113, 3836-3857.

(17) Nomura, K.; Liu, J.; Padmanabhan, S.; Kitiyanan, B. Nonbridged half-metallocenes containing anionic ancillary donor ligands: New promising candidates as catalysts for precise olefin polymerization. J. Mol. Catal. A: Chem. 2007, 267, 1-28.

(18) Nomura, K.; Liu, J. Half-titanocenes for precise olefin polymerisation: Effects of ligand substituents and some mechanistic aspects. Dalton Trans. 2011, 40, 7666-7682.

(19) For selected reviews (vanadium catalysts for olefin polymerization, refs 19-21), see: Hagen, H.; Boersma, J.; van Koten, G. Homogeneous vanadium-based catalysts for the Ziegler-Natta polymerization of $\alpha$-olefins. Chem. Soc. Rev. 2002, 31, 357-364.

(20) Gambarotta, S. Vanadium-based Ziegler-Natta: challenges, promises, problems. Coord. Chem. Rev. 2003, 237, 229-243.

(21) Nomura, K. In New Developments in Catalysis Research; Bevy, L. P., Ed.; NOVA Science Publishers: NY, 2005; pp 199-217.

(22) Some selected structural characterizations, reaction chemistry of V(III),(IV) methyl complex (refs 22-30) Hessen, B.; Teuben, J. H.; Lemmen, T. H.; Huffman, J. C.; Caulton, K. G. Monocyclopentadienylvanadium(III) and -vanadium(II) methyl, phenyl, and borohydride compounds. Organometallics 1985, 4, 946948.

(23) Hessen, B.; Lemmen, T. H.; Luttikhedde, H. J. G.; Teuben, J. H.; Petersen, J. L.; Jagner, S.; Huffman, J. C.; Caulton, K. G. Paramagnetic monocyclopentadienyl hydrocarbyl and borohydride compounds of vanadium(II) and vanadium(III). Synthesis, structure, and reactivity. Organometallics 1987, 6, 2354-2364.

(24) Hessen, B.; Meetama, A.; Teuben, J. H. Alkylidene complex of vanadium: synthesis and structure of cyclopentadienyl[bis(dimethylphosphino)ethane](neopentylidene)vanadium(III). J. Am. Chem. Soc. 1989, 111, 5977-5978.

(25) Gerlach, C. P.; Arnold, J. Synthesis and reactivity of a vanadium(III)-methyl complex stabilized by hexamethylsilazanate ligands. Organometallics 1996, 15, 5260-5262.

(26) Brussee, E. A. C.; Meetsma, A.; Hessen, B.; Teuben, J. H. Electron-deficient vanadium(III) alkyl and allyl complexes with amidinate ancillary ligands. Organometallics 1998, 17, 4090-4095.

(27) Aharonian, G.; Feghali, K.; Gambarotta, S.; Yap, G. P. A. Stability of trivalent vanadium alkyl and hydride supported by a chelating phosphinimido ligand. Organometallics 2001, 20, 2616-2622. 
(28) Feghali, K.; Harding, D. J.; Reardon, D.; Gambarotta, S.; Yap, G.; Wang, Q. Stability of metal-carbon bond versus metal reduction during ethylene polymerization promoted by a vanadium complex: The role of the aluminum cocatalyst. Organometallics 2002, 21, 968-976.

(29) Choukroun, R.; Lorber, C.; Donnadieu, B. Cationic vanadium(IV) methyl complexes $\left[\mathrm{Cp}_{2} \mathrm{VMe}\left(\mathrm{CH}_{3} \mathrm{CN}\right)\right]\left[\mathrm{B}\left(\mathrm{C}_{6} \mathrm{H}_{5}\right)_{4}\right]$ and $\left[\mathrm{Cp}_{2} \mathrm{VMe}(\mathrm{THF})\right]\left[\mathrm{MeB}\left(\mathrm{C}_{6} \mathrm{~F}_{5}\right)_{3}\right]$. Organometallics 2002, 21, 11241126.

(30) Liu, G.; Beetstra, D. J.; Meetsma, A.; Hessen, B. Neutral and cationic vanadium(III) alkyl and allyl complexes with a cyclopentadienyl-amine ancillary ligand. Organometallics 2004, 23, 39143920.

(31) Examples for structurally characterized V(V) alkyls at early stage (refs 31 and 32) de With, J.; Horton, A. D.; Orpen, A. G. Stable alkylvanadium $(\mathrm{V})$ compounds containing bulky imido and amido ligands. Organometallics 1990, 9, 2207-2209.

(32) Murphy, V. J.; Turner, H. Low-coordinate (arylimido)vanadium(V) alkyls: Synthesis and reactivity of $\mathrm{V}(\mathrm{NAr})\left(\mathrm{CH}_{2} \mathrm{Ph}\right)_{3}\left(\mathrm{Ar}=\mathrm{C}_{6} \mathrm{H}_{3}\right.$ 2,6- ${ }^{i} \mathrm{Pr}_{2}$ ). Organometallics 1997, 16, 2495-2497.

(33) Other examples at early stage (refs 33-38) Preuss, F.; Ogger, L. Alkylvanadium(V)-verbindungen darstellung und NMR-spektroskopische untersuchungen. Z. Naturforsch., B 1982, 37, 957-964.

(34) Devore, D. D.; Lichtenhan, J. D.; Takusagawa, F.; Maatta, E. Complexes of (arylimido)vanadium(V). Synthetic, structural, spectroscopic, and theoretical studies of $\mathrm{V}(\mathrm{Ntol}) \mathrm{Cl}_{3}$ and derivatives. J. Am. Chem. Soc. 1987, 109, 7408-7416.

(35) Preuss, F.; Becker, H.; Kraub, J.; Sheldrick, W. J. Darstellung und Struktur der zweikernigen tert-Butyliminovanadium(IV)-Komplexe: $\left[\left({ }^{t} \mathrm{C}_{4} \mathrm{H}_{9} \mathrm{~N}\right)_{2} \mathrm{~V}_{2} \mathrm{Cp}_{2} \mathrm{X}_{2}\right]\left(\mathrm{X}=\mathrm{O}^{t} \mathrm{C}_{4} \mathrm{H}_{9}, \mathrm{Cl}\right)$. Z. Naturforsch., B 1988, 43, $1195-1200$.

(36) Preuss, F.; Becker, H.; Wieland, T. tert-Butylimino-cyclopentadienyl-aIkylvanadium(V)-Verbindungen Darstellung und NMRspektroskopische Untersuchungen. Z. Naturforsch., B 1990, 45, 191198.

(37) Solan, G. A.; Cozzi, P. G.; Floriani, C.; Chiesi-Villa, A.; Rizzoli, C. Cyclodivanadazene alkyl and aryl complexes. Organometallics 1994, 13, 2572-2574.

(38) Chan, M. C. W.; Cole, J. M.; Gibson, V. C.; Howard, J. A. K. Novel $\mu$-methyl complexes of vanadium and their relevance to bimolecular deactivation of homogeneous imidovanadium polymerisation catalysts. Chem. Commun. 1997, 2345-2346.

(39) Recent reviews in vanadium complex catalysts (refs 12 and 39-41) Redshaw, C. Vanadium procatalysts bearing chelating aryloxides: structure-activity trends in ethylene polymerization. Dalton Trans. 2010, 39, 5595-5604.

(40) Nomura, K.; Zhang, W. Organometallic Reactions and Polymerization; Osakada, K., Ed.; The Lecture Notes in Chemistry 85; SpringerVerlag: Berlin, 2014; pp 89-118.

(41) Nomura, K.; Hou, X. Handbook of Transition Metal Polymerization Catalysts, 2nd ed.; Hoff, R., Ed.; Wiley: Hoboken, NJ, 2018; pp 313-338.

(42) Nomura, K.; Zhang, W. (Imido)vanadium(V)-alkyl, -alkylidene complexes exhibiting unique reactivity toward olefins and alcohols. Chem. Sci. 2010, 1, 161-173.

(43) Nomura, K.; Hou, X. Synthesis of vanadium-alkylidene complexes and their use as catalysts for ring opening metathesis polymerization. Dalton Trans. 2017, 46, 12-24.

(44) Zhang, S.; Zhang, W.; Nomura, K. Synthesis and reaction chemistry of alkylidene complexes with titanium, zirconium, vanadium, and niobium: Effective catalysts for olefin metathesis polymerization and the other organic transformations. Adv. Organomet. Chem. 2017, $68,93-136$.

(45) Kruse, W. Preparation of peralkylchromium(IV) compounds. J. Organomet. Chem. 1972, 42, C39-C42.

(46) Mowat, W.; Shortland, A. J.; Hill, N. J.; Wilkinson, G. Elimination stabilized alkyls. Part 11. Neopentyl and related alkyls of chromium(IV). J. Chem. Soc., Dalton Trans. 1973, 770-778. It has been known that the sensitivity of tetra(organo)chromium(IV) complexes toward air and moisture depend upon the nature of the organic ligands. Their reactivity toward oxygen and nitric oxide is in the order: methyl > neopentyl- trimethylsilylmethyl $>$ neophyl $\gg$ tritylmethyl

(47) Lubben, T. V.; Wolczanski, P. T.; van Duyne, G. D. Preparation of group $4 \mathrm{~B}$ complexes containing tri-tert-butylmethoxide (tritox), a steric cyclopentadienyl equivalent. Organometallics 1984, 3, 977-983.

(48) Nomura, K.; Onishi, Y.; Fujiki, M.; Yamada, J. Syntheses of various (arylimido)vanadium(V)-dialkyl complexes containing aryloxo and alkoxo ligands, and ring-opening metathesis polymerization using a vanadium(V)-alkylidene complex. Organometallics 2008, 27, 38183824.

(49) Nomura, K.; Matsumoto, Y. Unique reactivity of (arylimido)vanadium $(\mathrm{V})$ alkyl complexes with phenols: Fast phenoxy ligand exchange in the presence of vanadium(V) alkyls. Organometallics 2011, $30,3610-3618$.

(50) Hatagami, K.; Nomura, K. Synthesis of (adamantylmido)vanadium(V)-alkyl, alkylidene complex trapped with $\mathrm{PMe}_{3}$ : Reactions of the alkylidene complexes with phenols. Organometallics 2014, 33, $6585-6592$.

(51) Related study concerning the reaction mechanism by coordination of alcohol Zhang, W.; Katao, S.; Sun, W.-H.; Nomura, K. Synthesis of (1-adamantylimido)vanadium(V)-alkyl complexes containing a chelate alkoxo(imino)pyridine ligand, and reactions with alcohols $(\mathrm{ROH})$ that proceed via intermediates formed by coordination of ROH. Organometallics 2009, 28, 1558-1568.

(52) Nomura, K.; Suzuki, K.; Katao, S.; Matsumoto, Y. Ring-opening polymerization of THF by aryloxo-modified (imido)vanadium(V)alkyl complexes and ring-opening metathesis polymerization by highly active $\mathrm{V}\left(\mathrm{CHSiMe}_{3}\right)(\mathrm{NAd})\left(\mathrm{OC}_{6} \mathrm{~F}_{5}\right)\left(\mathrm{PMe}_{3}\right)_{2}$. Organometallics 2012, $31,5114-5120$.

(53) Hou, X.; Nomura, K. (Arylimido)vanadium(V)-alkylidene complexes containing fluorinated aryloxo and alkoxo ligands for fast living ring-opening metathesis polymerization (ROMP) and highly cisspecific ROMP. J. Am. Chem. Soc. 2015, 137, 4662-4665.

(54) Hou, X.; Nomura, K. Ring-opening metathesis polymerization of cyclic olefins by (arylimido)vanadium(V)-alkylidenes: highly active, thermally robust cis specific polymerization. J. Am. Chem. Soc. 2016, $138,11840-11849$.

(55) Chaimongkolkunasin, S.; Nomura, K. (Arylimido)vanadium(V)alkylidenes containing chlorinated phenoxy ligands: Thermally robust, highly active catalyst in ring-opening metathesis polymerization of cyclic olefins. Organometallics 2018, 37, 2064-2074.

(56) Zhang, W.; Nomura, K. Facile synthesis of (imido)vanadium(V)alkyl, alkylidene complexes containing an $\mathrm{N}$-heterocyclic carbene ligand from their trialkyl analogues. Organometallics 2008, 27, 6400-6402.

(57) Jover, J.; Bosque, R.; Sales, J. Neural Network Based QSPR Study for Predicting $\mathrm{p} K_{\mathrm{a}}$ of Phenols in Different Solvents. QSAR Comb. Sci. 2007, 26, 385-397.

(58) Kwiatkowska, E.; Majerz, I. Analysis of potential energy curve for proton motion in intermolecular hydrogen bond. Chem. Phys. Lett. 2010, 484, 134-138.

(59) Dawidowicz, A. L.; Kobielski, M.; Pieniadz, J. Anomalous relationship between free drug fraction and its total concentration in drug-protein systems: II. Binding of different ligands to plasma proteins. Eur. J. Pharm. Sci. 2008, 35, 136-141.

(60) For example Yi, J.; Yang, W.; Sun, W.-H.; Nomura, K.; Hada, M. Vanadium NMR chemical shifts of (imido)Vanadium(V) dichloride complexes with imidazolin-2-iminato and imidazolidin-2-iminato ligands: A cooperation with quantum-chemical calculations and multiple linear regression analyses. J. Phys. Chem. A 2017, 121, 9099-9105.

(61) Zhang, S.; Nomura, K. Highly efficient dimerization of ethylene by (imido)vanadium complexes containing (2-anilidomethyl)pyridine ligands: Notable ligand effect toward activity and selectivity. J. Am. Chem. Soc. 2010, 132, 4960-4965.

(62) Nomura, K.; Igarashi, A.; Zhang, W. J.; Sun, W.-H.; et al. Synthesis and structural analysis of (imido)vanadium $(\mathrm{V})$ complexes containing chelate (anilido)methyl-imine ligands: Ligand effect in ethylene dimerization. Inorg. Chem. 2013, 52, 2607-2614. 
(63) Buijink, J.-K. F.; Teubin, J. H.; Kooijman, H.; Spek, A. L. Synthesis, molecular structure, and reactivity of a half-sandwich vanadium(III) imido complex: The first vanadium(V) alkylidene.

Organometallics 1994, 13, 2922-2924. 